\title{
The impact of mixed-use development, small businesses, and walkability on carbon emissions in cool climate cities
}

Maged Zagow ( $\sim$ mzagow@hawk.iit.edu )

IIT: Illinois Institute of Technology https://orcid.org/0000-0002-1701-0411

\section{Research Article}

Keywords: United States (US), Chicago, zip codes, CO2 emissions

Posted Date: March 27th, 2023

DOl: https://doi.org/10.21203/rs.3.rs-1213981/v2

License: (9) (7) This work is licensed under a Creative Commons Attribution 4.0 International License. Read Full License 


\section{Abstract}

Cities in the United States (US) with a cool climate, such as Chicago and Boston, are experiencing a decrease in carbon emissions, possibly as a result of an emphasis on public transit and alternative energy sources. A dearth of dependable data on carbon emissions and urban comparison studies between metropolitan regions makes it difficult to support or refute ideal practices and policies. Thus, we evaluated the association between land use, walkability, socioeconomic characteristics, and carbon dioxide emissions at the level of the zip code. The current study analyzes the carbon footprints of four metropolitan locations in climatic zone 5 with a model of every US zip code in order to build a benchmarking prediction model for climate change in every US zip code. Our research indicates that in temperate climates, an increase in the number of enterprises within walking distance decreases CO2 emissions. This suggests that increasing the walkability of urban areas and renovating retail, art, entertainment, and leisure facilities in line with urban sustainability regulations can substantially reduce $\mathrm{CO} 2$ emissions.

\section{Introduction}

About half of the world's population resides in urban areas, and this proportion is projected to increase to sixty percent by 2030 . Cities consume $60-80 \%$ of the world's energy and emit a comparable proportion of carbon dioxide. According to the Organization for Economic Co-operation and Development (OECD), nations with greater urbanization produce more $\mathrm{CO} 2$ emissions. In OECD member cities, greenhouse gas (GHG) emissions are mostly generated by energyintensive services such as lighting, heating, cooling, appliance and electronic use, and transportation, rather than by industrial processes. Increasing urbanization is anticipated to result in a considerable increase in energy consumption and CO2 emissions, particularly in non-OECD Asian and African nations, where urban energy usage is projected to transition from CO2-neutral (biomass and trash) to CO2-intensive (coal and natural gas) energy sources (KamalChaoui 2009).

Energy consumption, and subsequently carbon emissions, are mostly affected by how electricity is generated and utilized in buildings, as well as how people travel within urban areas. The density and spatial organization of cities have a substantial effect on energy consumption, notably in the transportation and construction sectors. Densification has the potential to dramatically cut urban energy use. For instance, Japan's metropolitan districts are about five times denser than those of Canada, but consuming roughly 40 percent less energy. Countries with comparable geographical conditions and heating requirements, such as Denmark and Finland, have proportions that are reasonably comparable. Denmark's urban areas are four times denser than Finland's, yet the Danes consume around 40\% less energy than the Finns (OECD, Competitive Cities in the Global Economy 2006).

Urban carbon emissions are further influenced by the population's way of life, geographical arrangement, and accessibility to public transit. Consistently, North American nations that rely heavily on personal autos produce fifty percent higher $\mathrm{CO} 2$ emissions than European nations. Although the United States has the highest per capita carbon emissions among OECD member nations, Los Angeles, with its heavy reliance on personal automobiles, emits more CO2 than New York, which has the largest population density in the country (60 percent greater than Los Angeles) (OECD, The Economics of Climate Change Mitigation: Policies and Options for Global Act ion beyond 2012 2009).

There are several advantages to lowering carbon emissions. They include improvements to public health, cost savings and efficiency, energy security and infrastructure enhancements, and an improvement in the quality of life in metropolitan areas. These additional non-climate benefits may also help explain why metropolitan regions confront fewer trade-offs between economic development and greenhouse gas emission reduction. For instance, reductions in GHG emissions may improve human health to such an extent that they substantially offset the local costs of emissions reductions. Policies designed to reduce greenhouse gas emissions by increasing energy efficiency can result in substantial cost savings, and the energy savings can soon recoup the initial investment costs.

By improved urban design, energy consumption and carbon emissions may be minimized. Marshall's assertions (Marshall 2008) (Y. Chen, Estimating the relationship between urban forms and energy consumption: a case study in the Pearl River Delta, 2005-2008 2011) (R. Madlener 2011). According to (Breheny 1995) (O. Mindali 2004) (P. Rickwood 2008), There is a link between urban form, urban transportation energy use, and the associated carbon dioxide (CO2) emissions. (Steemers 2003).

Philippe Barlaa examined the elements that contribute to urban transportation's greenhouse gas emissions. Individual and household socioeconomic considerations, as well as land use and transportation supply characteristics in close proximity to a person's residence and place of employment, have an impact. They found that emissions are strongly dependent on the respondent's gender, professional position, age, family composition, and income. Land usage and public transit supply vary significantly between the two locations. According to him, there is a slight signal when calculating the elasticity of emissions in response to land use and transit supply factors, such as (Philippe Barlaa 2011).

According to (Brownstone 2009) and experience (Fang 2008), Land usage impacts the type of vehicle utilized. Logic dictates that a drop in greenhouse gas emissions should accompany any reduction in vehicle miles coming from an increase in mixed land use. Frank et al. (2011) found that the greenhouse gas emissions from mixed land use were about equivalent to those from automobile miles travelled (Lawrence D. Frank 2011). One of the key benefits of mixeduse development is the encouragement of walking and cycling as forms of mobility. In terms of pedestrian trips, the mixed-use benefit is greater than the reduction in automobile kilometers.

Promotion of walking and cycling as transportation modalities This is one of the main benefits of mixed-use construction. Mixed-use complexes have a greater impact on pedestrian miles traveled than on automobile miles traveled. They expect a $15 \%$ increase in walking trips for every $1 \%$ increase in land-use entropy and a 0.25 percent increase for every $1 \%$ decrease in walking distance to a store (Ewing 2010) (Kuzmyak 2006) (Boarnet 2008). 
We looked at a variety of spatial measures and approaches for describing urban shape in this research. Using our indices, we looked at the CO2 distribution, form, and fragmentation of urban neighborhoods as well as socioeconomic characteristics. CO2 emissions by zip code may be found for the entire country in the United States. To determine If mixed-use development is related to carbon emissions, then mixed-use development with a high number of businesses and more walkable will have a lower carbon emission.

So, why climate zone will affect the co2 emissions? According to (Harvey 2018), he claimed that rising carbon dioxide levels in the atmosphere might have a direct impact on the climate system. In other words, even if global temperatures remain stable, greater CO2 concentrations may continue to have an impact on the world. As a result, in addition to the Paris climate agreement's global temperature objectives of 2 degrees Celsius, some scientists are pushing for an explicit restriction on carbon dioxide concentrations (Harvey 2018). Regardless of what occurs with average global temperatures, scientists confirm that rising CO2 levels may lead to an increase in extreme weather and climate events (Nations 2021).

According to the latest data from the world's benchmark atmospheric monitoring station in Hawaii, the Mauna Loa Observatory, was released by the US National Oceanic and Atmospheric Administration and the Scripps Institution of Oceanography, reiterating how carbon dioxide (CO2) emissions continue to be a key driver of climate change. And because $\mathrm{CO} 2$ has a long lifetime in the atmosphere many generations would likely endure a series of natural shocks linked to climate change like rising temperatures, more extreme weather, melting ice, rising sea level and all the associated impacts (Nations 2021).

Moreover, why we choose climate zoon 5 ? Although that cities like Chicago and Boston in cool climate is witnessing a reduction in carbon emissions, but still witnessing extreme weather and climate events that affect those cities. It focusses more on public transportation, and alternative energy resources, but mixeduse development, and increasing small businesses in walkable district decrease carbon emissions. It's difficult to validate or deny optimal practices and regulations due to a lack of reliable data on carbon emissions and urban comparative study amongst metropolitan areas. We looked at the link between land use, walkability, socioeconomics variables and carbon dioxide emissions at the zip code level. It's important to know if and how land use changes impact carbon emissions.

Data on census tracts, geographic characteristics, and pertinent socioeconomic indicators identified in the literature study are used to fulfil the stated goal. Using this information, we looked at how number of businesses, walkability and the socio-economic and geographical factors that define US urban form interact. Such connections have significant policy implications for the development of low carbon cities in the United States, where city governments have centered their carbon mitigation approach primarily around transportation and infrastructure. We believe that our research will add to the ongoing discussion on the relationship between urban design and $\mathrm{CO}_{2}$ emissions and help us better understand the role that spatial form plays in sustainable urban development.

Insert Figure 1 US climate regions (Council 2012)

Insert Table 1 climate zones definitions (Amanda D. Smith 2014)

\section{Cool climate - Zone 5}

Zone 5 of the IECC depicts the United States' cold climate. A region with a cold climate has between 5,400 and 9,000 heating degree days (with $65^{\circ} \mathrm{F}$ as the base temperature). A continental climate is characterized by severely cold and snowy winters and mild to hot summers with frequent thunderstorms. In this location, many air masses collide, including those from Canada and the Gulf of Mexico. As a result, our climate is unpredictable, with spells of bad weather mixed with days of brilliant sunshine and fast shifts in temperature, humidity, cloudiness, and wind direction.

Rainfall is abundant in zoon 5 , with an average annual precipitation of 1,100 millimeters (43 inches). Also, it is evenly distributed throughout the year. Winter is characterized by snowfall, whilst summer is characterized by afternoon or evening thunderstorms and various meteorological disturbances that may result in rainy days (Council 2012).

From December through mid-March, the winter season is severely cold, with daily highs around $0^{\circ} \mathrm{C}\left(32^{\circ} \mathrm{F}\right)$ and lows as low as $-15^{\circ} \mathrm{C}(\mathrm{five}$ degrees Fahrenheit). Blizzards, which generate high-velocity ice and snow gusts, may make it seem considerably colder. When the conditions are appropriate, snowfalls can be substantial enough to generate actual snowstorms. Many weeks of snowfall bury the countryside (Energy n.d.).

From mid-March through mid-June, the weather is unstable, with lovely days punctured by the return of frosty conditions. Throughout the winter months of March and even April, it may snow often, particularly at the beginning of the month when it is still chilly. Even though it is still early in the year, temperatures have already reached or above 25 degrees Celsius (77 degrees Fahrenheit).

From mid-June to the end of August, the weather is warm and humid. During this season, temperatures can range from chilly, wet days with a high of $23 / 24{ }^{\circ} \mathrm{C}$ $\left(73 / 75^{\circ} \mathrm{F}\right)$ to sweltering, humid days with a high of $28^{\circ} \mathrm{C}\left(82^{\circ} \mathrm{F}\right)$ when the sun is shining and a sea breeze is blowing. Sometimes, heat waves can develop, with daytime temperatures reaching or exceeding $35^{\circ} \mathrm{C}\left(95^{\circ} \mathrm{F}\right)$ and nocturnal temperatures hanging around $23 / 25^{\circ} \mathrm{C}\left(73 / 77^{\circ} \mathrm{F}\right)$. Summer's bright days are pleasant, although they are frequently interrupted by strong afternoon thunderstorms, sometimes accompanied by hail.

Page 3/26 
Autumn, from September through November, is the warmest and most consistent season of the year. Although while the weather is still hot and humid in early September, with bright sky and a few afternoon thunderstorms, the temperature decreases rapidly until the middle of October, when it starts to turn cold. Even in November, temperatures are falling and the first snowfalls may have begun. This period of year is characterized by frequent rainfall.

In the frigid climate, there are four distinct seasons, each with its unique set of circumstances. There is a broad variety of precipitation types and amounts, with small average monthly and seasonal changes. There is a tremendous degree of variance in the metropolitan area's annual weather conditions. There are several storms throughout the year.

Data sources

Using Census Bureau data, zip code demographics, and a block census, the figures were compiled. Between 1990 and 2010 , the US Census Bureau utilized three separate waves of data. Comparing zone variety in residential and nonresidential zones requires demographic data with precisely defined geographic boundaries. In this technique, which employs a variety of land-use categories, only residential land-use categories are employed to measure diversity. Understanding a city's demographics requires familiarity with its zip code distribution. Using zip code demographics, you may evaluate patterns within a city and even focus your search to a specific location. The information contained in a zip code can also disclose socioeconomic characteristics such as a person's wealth and level of education.

Since 1994, under the moniker "Zip Code Business Patterns," the census has gathered significant data on the total number of firms in each zip code. This data includes businesses with a financial motive, such as supermarkets and graphic design firms, as well as nonprofit and government organizations, such as museums and religious institutions. In addition, supermarkets and graphic design businesses are included. It also gives additional statistics on the number of firms per employment size class, which specifies the employment level and employment dynamics by company size.Research variables

Insert Table $2 \mathrm{CO}_{2}$ Emission Regression analysis Variables

\section{Urban factors}

1. Street factor; Reid Ewing and Shima Hamidi built a countrywide database of junction street locations in 2010, including a count of streets that meet at each intersection, using a TomTom national data collection of street centerlines that ships for ArcGIS from 2006. There is a centerline feature in the TomTom data collection for every road segment linking nearby junctions, indicating that every intersection is the spatially coincident terminal of at least three road segments. (Hamidi 2010).[1]

2. Mix factor; Estimating all three groups of residents in each zip code yielded a mix factor. To establish the mix factor.

The Office of Management and Budget (OMB) classifies the United States into metropolitan and micropolitan statistical zones using Census Bureau data. Depending on the definition, metropolitan or micropolitan statistical regions have a core population nucleus and adjacent communities that are economically and socially connected with the core. 2010 requirements stipulate that CBSA must have at least one city with a population of 10,000 or more. Each metropolitan area must contain at least one urbanized region with at least 50,000 inhabitants. A micropolitan statistical region must contain a minimum urban cluster of 10,000 people and a maximum of 50,000 persons. A "central county" is one in which at least half the population resides in urban districts with a population of 10,000 or more, or where at least 5,000 people reside in a single urban area with a population of 10,000 or more (counties). According to specific criteria, CBSA includes "outlying counties" that travel to or from the core counties (Census 2020).

Comparative analysis: Nine Urban models

Insert Table 3 Number of cases for each urban model

Insert Figure 2 Descriptive Statistics of $\mathrm{CO}_{2}$ emissions for each model

\section{Results And Descriptions}

Correlation analysis:

Insert Figure 3. Pearson Correlation between $\mathrm{CO} 2$ emissions and urban Socioeconomics Variables.

Insert Table 4. Pearson Correlation between $\mathrm{CO}_{2}$ emissions and urban Socioeconomics Variables. 
Each zip code's $\mathrm{CO} 2$ emissions are directly proportionate to the number of vehicle miles travelled. This relationship confirms the hypothesis that the longer a vehicle is driven, the more $\mathrm{CO} 2$ it produces. $\mathrm{CO} 2$ emissions per zip code are negatively correlated with overall business count. One argument is that as a zip code's business population expands, so does its transportation infrastructure, resulting in a decrease in $\mathrm{CO} 2$ emissions. Public transportation use is often inversely linked to per-zip-code $\mathrm{CO} 2$ emissions. As more people utilize public transportation, less $\mathrm{CO} 2$ is emitted into the atmosphere. The Walkscore and perzip-code $\mathrm{CO} 2$ emissions show a weak linear relationship. This relationship supports the hypothesis that as more people walk to fulfill their needs, less $\mathrm{CO} 2$ is emitted into the environment. Regression analysis reveals that numerous metropolitan locations in climatic zone 5 exhibit critical values, as seen in Figure 4. Red (blue) regions indicate that $\mathrm{CO} 2$ emissions often sell for a considerably higher (lower) price in that zip code compared to all other US zip codes.

Insert Figure 4. Heat map based on residuals extracted from a regression featuring $\mathrm{CO}_{2}$ emissions for All US zip codes.

Insert Figure 5. Heat map based on residuals extracted from a regression featuring $\mathrm{CO}_{2}$ emissions for Cool climate zone 5 zip codes

Zone 5 CITEIS

The quantity of carbon dioxide emitted each zip code is related to the number of miles travelled. This correlation supports the notion that longer trips produce more C02. Population density is negatively related with $\mathrm{CO} 2$ emissions per zip code. As more people utilize public transportation, less $\mathrm{CO} 2$ is emitted into the atmosphere. $\mathrm{CO} 2$ emissions per zip code are inversely proportional to the number of enterprises in that area. According to one theory, using public transportation reduces carbon dioxide emissions. $\mathrm{CO} 2$ emissions per zip code have a slight inverse linear relationship with retail establishments. The quantity of $\mathrm{CO} 2$ emitted into the environment reduces as more retail establishments support public transportation. Using public transportation to support increased Accommodation and Food Services reduces $\mathrm{CO} 2$ emissions. Public transportation use is often inversely linked to per-zip-code $\mathrm{CO} 2$ emissions. This is consistent with the expectation that less $\mathrm{CO} 2$ would be emitted into the environment if more people walked or worked from home. $\mathrm{CO} 2$ emissions per zip code are often inversely related to the land use composition. Consumers may be able to access more services in a single zip code with less driving, hence decreasing $\mathrm{CO} 2$ emissions. The Walkscore and per-zip-code $\mathrm{CO} 2$ emissions show a weak linear relationship. This relationship supports the hypothesis that as more people walk to fulfill their needs, less $\mathrm{CO} 2$ is emitted into the environment. Figure 6 demonstrates via regression analysis that many cities in climatic zone 5 experience critical levels. Red (blue) spots indicate that $\mathrm{CO} 2$ emissions often sell for a comparatively higher (lower) price in that zip code.

Insert Figure 6. Heat map based on residuals extracted from a regression featuring $\mathrm{CO}_{2}$ emissions for Cool climate zone 5 cities zip codes

\section{Zone 5 METRO}

Significant upward (positive) linear correlation exists between $\mathrm{CO} 2$ emissions per zip code and vehicle kilometers traveled. This research indicates that longer routes result in increased $\mathrm{CO} 2$ emissions. There is a modest negative linear correlation between retail shops and $\mathrm{CO} 2$ emissions per zip code. One argument is that boosting public transportation usage reduces $\mathrm{CO} 2$ emissions. There is a weak correlation between the hotel and food services industries and $\mathrm{CO} 2$ emissions per zip code. Using public transit to support additional hotel and eating services reduces $\mathrm{CO} 2$ emissions. In general, population density and CO2 emissions are inversely related. As more individuals use public transit, $\mathrm{CO} 2$ emissions are reduced. $\mathrm{CO} 2$ emissions are proportionate to each zip code's land use composition. As more land uses are merged, fewer people travel, which lowers carbon dioxide emissions. The Walkscore and per-zip-code CO2 emissions show a weak linear relationship. This relationship supports the claim that an increase in the number of individuals who walk reduces $\mathrm{CO} 2 \mathrm{emissions.} \mathrm{CO} 2$ emissions are inversely related to the number of occupied housing units per zip code. More $\mathrm{CO} 2$ emissions in a zip code may be attributable to a greater population density. Regression analysis reveals that many metropolitan locations in climatic zone 5 exhibit critical values, as seen in Figure 7. Red (blue) spots indicate that $\mathrm{CO} 2$ emissions often sell for a comparatively higher (lower) price in that zip code.

Insert Figure 7. Heat map based on residuals extracted from a regression featuring $\mathrm{CO}_{2}$ emissions for Cool climate zone 5 Metro zip codes 
The quantity of carbon dioxide emitted each zip code is related to the number of miles travelled. This correlation supports the notion that longer trips produce more CO2. Using public transportation to support increased Accommodation and Food Services reduces $\mathrm{CO} 2$ emissions. The relationship between CO2 emissions per zip code and retail shop sales is inverse. If more retail establishments support public transit, $\mathrm{CO} 2$ emissions to the atmosphere might be decreased. There is a weakly positive linear link between residential occupancy and $\mathrm{CO} 2$ emissions per zip code. As the number of occupied residential units in a given zip code increases, $\mathrm{CO} 2$ emissions also increase. The correlation between household income and $\mathrm{CO} 2$ emissions by zip code is substantial. One theory is that as family income increases, so do $\mathrm{CO} 2$ emissions.

According to Figure 8, regression analysis reveals that micro regions in climatic zone 5 exhibit a minimal value.

Insert Figure 8. Heat map based on residuals extracted from a regression featuring $\mathrm{CO}_{2}$ emissions for Cool climate zone 5 Micro zip codes

Boston Metro- Massachusetts

The quantity of carbon dioxide emitted each zip code is related to the number of miles travelled. This correlation supports the notion that longer trips produce more $\mathrm{CO}$. The Walkscore and per-zip-code $\mathrm{CO} 2$ emissions show a weak linear relationship. This relationship supports the hypothesis that as more people walk to fulfill their needs, less $\mathrm{CO} 2$ is emitted into the environment. Using public transportation to support increased Accommodation and Food Services reduces $\mathrm{CO} 2$ emissions. The use of public transportation has a negative correlation with $\mathrm{CO} 2$ emissions per zip code. Civic and social groups may encourage individuals to engage in more ecologically friendly and sustainable activities. If more retail establishments support public transit, $\mathrm{CO} 2 \mathrm{emissions} \mathrm{to} \mathrm{the}$ atmosphere might be decreased. In general, the street factor has a negative correlation with $\mathrm{CO} 2$ emissions per zip code. If there were more street crossings, people would not have to go as far, hence lowering $\mathrm{CO} 2$ emissions. The correlation between $\mathrm{CO} 2$ emissions per zip code and the proportion of occupied housing units is positive. As the number of occupied residential units in a given zip code increases, $\mathrm{CO} 2$ emissions also increase. According to Figure 9 , regression analysis reveals that the west side of Boston experiences crucial levels. Red (blue) spots indicate that $\mathrm{CO} 2$ emissions often sell for a comparatively higher (lower) price in that zip code.

Insert Figure 9. Heat map based on residuals extracted from a regression featuring $\mathrm{CO}_{2}$ emissions for Boston Metro zip codes

Chicago Metro - Illinois

The quantity of carbon dioxide emitted each zip code is related to the number of miles travelled. This correlation supports the notion that longer trips produce more $\mathrm{CO} 2$. The Walkscore shows a high correlation with per-zip-code $\mathrm{CO} 2$ emissions. This relationship supports the hypothesis that as more people walk to fulfill their needs, less $\mathrm{CO} 2$ is emitted into the environment. The mix factor is inversely proportional to $\mathrm{CO} 2$ emissions per zip code. Individuals will be able to access more services inside a single zip code if the employment-to-population ratio improves, jobs mix, and more people walk. CO2 emissions per zip code have a slight inverse linear relationship with retail establishments. If more retail establishments support public transit, $\mathrm{CO} 2 \mathrm{emissions}$ to the atmosphere might be decreased. The association between health care facilities and $\mathrm{CO} 2$ emissions per zip code is negative. Public transportation, for instance, reduces $\mathrm{CO} 2$ emissions. There is a negative linear relationship between finance facilities and $\mathrm{CO} 2$ emissions per zip code. Using public transportation, for instance, reduces the quantity of $\mathrm{CO} 2$ emitted into the atmosphere. In general, the street factor has a negative correlation with $\mathrm{CO} 2$ emissions per zip code. If there were more street crossings, people would not have to go as far, hence lowering $\mathrm{CO} 2$ emissions. Regression analysis reveals that the north side of Chicago is experiencing critical values, as seen in Figure 10. Red (blue) spots indicate that $\mathrm{CO} 2$ emissions often sell for a comparatively higher (lower) price in that zip code.

Insert Figure 10. Heat map based on residuals extracted from a regression featuring $\mathrm{CO}_{2}$ emissions for Chicago Metro zip codes 
There is a substantial correlation between the number of occupied dwelling units and $\mathrm{CO} 2$ emissions per zip code. As the number of occupied residential units in a given zip code increases, $\mathrm{CO} 2$ emissions also increase. The Walkscore shows a high correlation with per-zip-code $\mathrm{CO} 2$ emissions. This relationship supports the hypothesis that as more people walk to fulfill their requirements, less $\mathrm{CO} 2$ will be emitted into the environment. Population density is negatively related with $\mathrm{CO} 2$ emissions per zip code. As more people utilize public transportation, less $\mathrm{CO} 2$ is emitted into the atmosphere. $\mathrm{CO} 2$ emissions by zip code correlate considerably with land use mix. Consumers may be able to access more services in a single zip code with less driving, hence decreasing CO2 emissions. The association between the utilization of public transportation and $\mathrm{CO} 2$ emissions by zip code is significantly negative and linear. The mix factor is inversely proportional to $\mathrm{CO} 2$ emissions per zip code. $\mathrm{CO} 2$ emissions per zip code are negatively correlated with business density. One argument is that as a zip code's business population expands, so does its transportation infrastructure, resulting in a decrease in $\mathrm{CO} 2$ emissions. Environmental and animal groups have a weakly negative linear relationship with $\mathrm{CO} 2$ emissions. Environmental and animal groups may inspire individuals to adopt more sustainable and ecofriendly habits. $\mathrm{CO} 2$ emissions per zip code have a substantial inverse linear relationship with these categories. Civic and social groups may encourage individuals to engage in more ecologically friendly and sustainable activities. According to Figure 11, we see via regression analysis that the center of Columbus is experiencing critical levels. Red (blue) spots indicate that $\mathrm{CO} 2$ emissions often sell for a comparatively higher (lower) price in that zip code.

Insert Figure 11. Heat map based on residuals extracted from a regression featuring $\mathrm{CO}_{2}$ emissions for Columbus Metro zip codes

Detroit Metro - Michigan

$\mathrm{CO} 2$ emissions are strongly correlated with gas mileage per zip code. According to this webpage, longer journeys produce more $\mathrm{CO} 2$. The correlation between walkscore and $\mathrm{CO} 2$ emissions per zip code is considerable. This link is supported by the fact that when more people walk, less $\mathrm{CO} 2$ is emitted into the atmosphere. Population density is inversely related to $\mathrm{CO} 2$ emissions per zip code. As more people utilize public transportation, less $\mathrm{CO} 2$ is emitted into the atmosphere. There is a large negative linear association between transit usage and $\mathrm{CO} 2$ emissions by zip code. As more people utilize public transportation, less $\mathrm{CO} 2$ is emitted into the atmosphere. The relationship between Climate Change and Civic \& Social Organizations is substantial. Civic and social groups may motivate individuals to be more environmentally conscious. $\mathrm{CO} 2$ emissions are negatively correlated with the mix factor. Increasing the usage of public transportation reduces carbon dioxide emissions. $\mathrm{CO} 2$ emissions by zip code are negatively correlated with street factor. Many individuals might save time and money by reducing their driving distance. According to Figure 12, we see via regression analysis that the core of Detroit is experiencing critical levels. Red (blue) spots indicate that $\mathrm{CO} 2$ emissions often sell for a comparatively higher (lower) price in that zip code.

Insert Figure 12. Heat map based on residuals extracted from a regression featuring $\mathrm{CO}_{2}$ emissions for Detroit Metro zip codes

\section{Methodology And Techniques}

Our regression study includes three important categories: CO2 emissions, the number of enterprises, and the walkscore. We developed a statistical regression model for each category using US Census zip code data. The ordinary least square (OLS) method was utilized with the following predictor variables:

Percentage of Occupied Housing Units, Percentage of People Utilizing Public Transportation, Environmental and Wildlife Organizations, Vehicle Miles Traveled, Retail Trade Facilities, Arts, Entertainment, and Recreation Facilities, Accommodations and Food Services, Street Factor, and Mix Factor (see Table 2 for a sample of specific variables used). ${ }^{*} 0.05,{ }^{* *} p 0.01$; adjusted R2, which is a measure of the line's quality of fit. Not all variables are utilized in each regression, and the absence of variables in columns indicates that they are not significant for the particular regression.

The model can be formulated as

$$
\ln E j=\beta j 0+\sum_{i} \beta i j \cdot \mathrm{X} \iota+\epsilon j
$$

Where j represents the categories of number of companies and walkscore, Ej represents $\mathrm{CO} 2$ emissions for each zip code, and Xi represents the predictor variable whose value is derived from our collection of census data for prediction. Using shape files and geographic information systems (GIS), we mapped zip codes to cool climate zoon 5 divisions. Due to the properties of the OLS approach, this method will still provide estimates of the mean that are not skewed. To indicate the degree of uncertainty of a random variable that is a product of other random variables, correlation coefficients between the original variables must be available for each zip code region. In practice, however, we lack the information in the census dataset, thus we cannot determine the amount of their uncertainty. 
Insert Table 5. Carbon Emissions, Number of Businesses, and Walkscore Regression Analysis for All US Zip Codes, Climate zoon 5 Cities, Climate zoon 5 Metro Areas, and Climate zoon 5 Micro Areas.

Insert Table 6. Carbon Emissions, Number of Businesses, and Walkscore Regression Study for Boston, Chicago, Columbus, and Detroit.

The prediction intervals for each zip code region are computed using the mean points of the explanatory variables. To do this, we ran mean-centered regressions on each of the nine models and examined the $95 \%$ confidence intervals around the intercepts.

\section{Regressions And Results}

Regression is distinct from correlation in that it aims to include variables into an equation and explain their causal relationship. I must create a model using linear regression, often known as linear modelling, since l'm attempting to explain natural occurrences using equations that only represent a fraction of the whole picture. This section presents the results of the linear regression as well as several data sets. This section also provides theoretical explanations and predictions for the observed relationships between the dependent variable and the independent factors.

The model summary presents the statistical measure of the quality of fit and the modified R Square coefficients of determination. The modified R Square values vary from 0 to 1 , indicating the degree to which the regression line fits the data points, where 1 denotes a perfect fit. Hence, a greater adjusted $R$ Square value suggests a more accurate regression model. The ANOVA table displays the regression model's significance level. The coefficient table displays the slopes of the independent variables and the constant (intercept).

\section{Finding For Research}

In zone 5 of the Metro and Micro Areas Urban Model, it was intriguing to see that as the overall number of enterprises increased, so did carbon emissions. We find the reverse when we examine the metropolitan areas of Boston, Columbus, and Detroit. Further on the hybrid and low, dense metropolis models, the hybrid metropolis model reveals more carbon emissions than the low, dense metropolis model. The hybrid metropolis concept is expected to have the effect of attracting additional buildings and automobiles, hence contributing to air pollution.

(tCO2 e/yr) has a negative correlation with the proportion of people who ride public transportation. An rise in the number of firms that release carbon dioxide seems to help the reduction of carbon emissions. What services or facilities, if any, contribute to greater carbon emissions? The upward (positive) linear association between carbon emissions and shopping, the arts, entertainment, and leisure shows no indication of diminishing.

Therefore, what can be done in zone 5 with a cold climate to reduce carbon emissions? Given the patterns of urbanization and mixed-use diversity that have been disclosed, what kind of carbon emission technologies make sense? It makes sense to add strategies to cope with urban, mixed-use expansion while simultaneously expanding public transportation alternatives. To reduce carbon emissions, planners must prioritize areas with a low street factor and a limited number of housing units. To decrease or preserve greenhouse gas emissions, it would be prudent to repurpose these regions as retail, arts, entertainment, and leisure destinations.

What is the mechanism for managing and regulating the mix of land uses in these situations? In climatic zone 5 with a cool climate, a metropolitan area with a variety of residential zones and a balance of uses may result in fewer carbon emissions. Increasing the proportion of arts, entertainment, and amusement in the design may reduce carbon emissions.

According to one of our studies, geolocation correlation may result in inaccurate conclusions. According to my study, the number of businesses in a region has a negative correlation with $\mathrm{CO} 2$ emissions. I observed that the results of the test for correlation were inconsistent. At the city level, there is a declining tendency. According to the city variation research, the total (tCO2e/year) and total number of businesses have a negative relationship. It has a greater number of multi-family structures than the total (tCO2e/year).

\section{General Conclusion}

The study found that zone 5 metropolitan areas with a cool temperature provide a healthy environment for people to live in. Individuals may opt to live in these areas due to the reduced energy and $\mathrm{CO} 2$ emissions of public transportation, the greater availability of recreational activities, and the higher population density. According to the study, increases in mixed-use facility density lower carbon emissions. Yet, tiny, low-population regions have larger carbon emissions than metropolitan places. First, as more facilities are constructed, the need for public and shared mobility increases. As a result, a larger percentage of the region must utilize more fossil fuels for heating and cooling.

According to the conclusions of this study, well-planned mixed land use within communities has diverse effects on carbon emissions. The following variables should be considered when designing mixed-use zones, according to the study:

- The type of mixed-use development chosen should blend in with the neighborhood.

- Commercial developments should take environmental consideration to be acceptable for the community, scaled to match the size of the neighborhood, and provide pedestrians with easy access. 
- Retail, arts, entertainment, recreation, and public parks may help reduce carbon emissions. While searching for ways to reduce a city's carbon footprint, public transportation is one of the most crucial things to consider. Municipalities should invest on public transportation. To eliminate carbon emissions totally, walk or ride a bicycle wherever possible. By dispersing $\mathrm{CO} 2$ emissions across several individuals, carpooling and public transportation reduce $\mathrm{CO} 2$ emissions dramatically. If electric vehicles are charged with clean electricity, they emit no $\mathrm{CO} 2$ emissions.

There is a linkage between regulatory instruments such as land use, human needs, and environmental considerations, and this study's findings indicate that a greater understanding of this relationship is required. To address this complexity, it will be required to move beyond Jane Jacobs' criteria and the construction of distinct mixed-use zones. Clearly, more effort must be exerted.

Cities and regions may foster green growth through innovative procurement, enhanced screening of infrastructure, transportation, communication networks, and utilities, financial and tax incentives, energy supplier partnerships and regulation, consumer awareness, and green employment training programs. In addition, they have a substantial degree of responsibility for leading by example. An successful green growth plan for cities should prioritize short- to mediumterm job creation and systemic changes in the way cities run and expand via the continuous development and implementation of new technologies that boost connectivity and minimize resource consumption. The public-private partnerships generated by green infrastructure funds have the potential to significantly reduce the burden on local governments while enhancing the effectiveness of green investments.

\section{References}

Agency, Illinois Environmental Protection. 2019. Climate Change in Illinois. January 23. Accessed November 16, 2021.

https://www2.illinois.gov/epa/topics/climate/Pages/default.aspx.

Amanda D. Smith, and Pedro J. Mago. 2014. "Effects of Load-following operational methods on combined heat and power systemefficiency." Applied Energy 337-351.

B.C. O’Neill, M. Dalton, R. Fuchs, L. Jiang, S. Pachauri, K. Zigova. 2010. "Global demographic trends and future carbon emissions ." Proceedings of the National Academy of Sciences 17521-17526.

Boarnet, M.G., Greenwald, M., and McMillan, T. 2008. "Walking, Urban Design, and Health: Toward a Cost-Benefit Analysis Framework." Journal of Planning Education and Research 341-358.

Breheny, M. 1995. "The compact city and transport energy consumption ." Transactions of Institute of British Geographers 81-101.

Brownstone, D. and Golob, T. 2009. "The Impact of Residential Density on Vehicle Usage and Energy Consumption." Journal of Urban Economics 91-98.

C.S.B Grimmond, T.S King, F.D Cropley, D.J Nowak, C Souch. 2002. "Local-scale fluxes of carbon dioxide in urban environments: methodological challenges and results from Chicago." Environmental Pollution S243-S254.

Census. 2020. Metropolitan and Micropolitan. April 1. Accessed October 7, 2021. https://www.census.gov/programs-surveys/metro-micro/about.html.

Conor K. Gately, Lucy R. Hutyra, and lan Sue Wing. 2015. "Cities, traffic, and CO2: A multidecadal assessment of trends, drivers, and scaling relationships." PNAS 4999-5004.

Council, International Code. 2012. 2012 IECC - International Energy Conservation Code. ICC. https://basc.pnnl.gov/images/iecc-climate-zone-map.

Dan Tong, Qiang Zhang, Yixuan Zheng, Ken Caldeira, Christine Shearer, Chaopeng Hong, Yue Qin \& Steven J. Davis. 2019. "Committed emissions from existing energy infrastructure jeopardize $1.5^{\circ} \mathrm{C}$ climate target." Nature $373-377$.

Dhakal, S. 2008. "Climate change and cities: the making of a climate friendly future." In Urban Energy Transition: From Fossil Fuel to Renewable Power, by P. Droege, 173-182. Oxford: Elsevier.

Energy, Office of Energy Efficiency \& Renewable. n.d. Climate Zones buildings. Accessed November 2, 2021. https://www.energy.gov/eere/buildings/climatezones.

Ewing, R. and Cervero, R. 2010. "Travel and the Built Environment: A Meta-Analysis." Journal of the American Planning Association $265-294$.

Fang, H.A. 2008. "A discrete-continuous model of households' vehicle choice and usage with an application to the effects of residential density."

Transportation Research 736-758.

Gehl, Jan. 1980. Life Between Buildings. Island Press.

Gustafson, E.J. 1998. "Quantifying landscape spatial pattern: what is the state of the art? ." Ecosystems 143-156.

Hamidi, Reid Ewing and Shima. 2010. Measuring Urban Sprawl and Validating Sprawl Measures. University of Utah, National Institutes of Health, 114. Accessed 14, 2015. http://gis.cancer.gov/tools/urban-sprawl/.

Harvey, Chelsea. 2018. CO2 Can Directly Impact Extreme Weather, Research Suggests . June 21. Accessed November 16, 2021. https://www.scientificamerican.com/article/co2-can-directly-impact-extreme-weather-research-suggests/.

Page $9 / 26$ 
Hugh S. Baker, Richard J. Millar, David J. Karoly, Urs Beyerle, Benoit P. Guillod, Dann Mitchell, Hideo Shiogama, Sarah Sparrow, Tim Woollings \& Myles R. Allen. 2018. "Higher $\mathrm{CO} 2$ concentrations increase extreme event risk in a $1.5^{\circ} \mathrm{C}$ world ." Nature Climate Change 604-608.

J. Huang, X.X. Lu, J.M.A. Sellers. 2007. "A global comparative analysis of urban form: applying spatial metrics and remote sensing ." Landscape and Urban Planning 184-197.

K. McGarigal, S.A. Cushman, M.C. Neel, E. Ene. 2002. FRAGSTATS: Spatial Pattern Analysis Program for Categorical Maps.

http://www.umass.edu/landeco/research/fragstats/fragstats.html.

Kamal-Chaoui, Lamia and Alexis Robert. 2009. Competitive Cities and Climate Change. PARIS: OECD.

Kuzmyak, R., Baber,C. and Savory, D. 2006. "Use of a walk opportunities index to quantify local accessibility." Transportation Research 145-153.

Lawrence D. Frank, Michael J. Greenwald, Sarah Kavage, Andrew Devlin. 2011. AN ASSESSMENT OF URBAN FORM AND PEDESTRIAN AND TRANSIT

IMPROVEMENTS AS AN INTEGRATED GHG REDUCTION STRATEGY. Seattle, WA: The State of Washington, Department of Transportation .

M. Herold, J. Scepan, K.C. Clarke. 2002. "The use of remote sensing and landscape metrics to describe structures and changes in urban land uses ." Environment and Planning A 1443-1458.

M. Herold, X.H. Liu, K.C. Clarke. 2003. "Spatial metrics and image texture for mapping urban land use ." Photogrammetric Engineering \& Remote Sensing 9911001.

M.G. Turner, R.H. Gardner, R.V. O’Neill. 2001. "Landscape Ecology in Theory and Practice. Pattern and Process." 99-108. New York: Springer-Verlag.

Maher, Kris. 2019. "U.S. Carbon Emissions Rose 3.4\% in 2018 as Economy Surged." The Wall Street Journal, January 8.

Marshall Lindsey, Joseph L. Schofer, Pablo Durango-Cohen, Kimberly A. Gray. 2011. "The effect of residential location on vehicle miles of travel, energy consumption and greenhouse gas emissions: Chicago case study." Transportation Research Part D: Transport and Environment 1-9.

Marshall, J.D. 2008. "Energy-efficient urban form ." Environmental Science \& Technology 3133-3137.

Massachusetts, Commonwealth of. 2018. Climate Change Planning Efforts. December. Accessed November 16, 2021. https://www.mass.gov/infodetails/climate-change-planning-efforts.

-. 2021. GHG Emissions and Mitigation Policies. Accessed November 16, 2021. https://www.mass.gov/info-details/ghg-emissions-and-mitigation-policies.

Nadja Popovich, Denise Lu. 2019. The Most Detailed Map of Auto Emissions in America. October 10.

https://www.nytimes.com/interactive/2019/10/10/climate/driving-emissions-map.html?mc=adintl\&ad-

keywords=Int|AudDev\&subid1=TAFI\&fbclid=IwAR1uj0bisIYPSTe1 oxdLx20JTKe_vH8tHZuR9cic1uUMrPpZxaR_daEXeUE\&dclid=CIzetrzaoOYCFS8C0wodwc8GC

Nations, United. 2021. Chilliest Spring in years is cold comfort as CO2 emissions rise: WMO . June 8. Accessed November 16, 2021.

https://news.un.org/en/story/2021/06/1093592.

NESCOE. 2020. New England States Vision Statement . October 16. Accessed November 16, 2021. https://nescoe.com/resource-center/vision-stmtoct2020/\#_ftn1.

O. Mindali, A. Raveh, I. Salomon. 2004. "Urban density and energy consumption: a new look at old statistics ." Transportation Research Part A $143-162$.

OECD. 2006. Competitive Cities in the Global Economy. Paris: OECD.

OECD. 2009. The Economics of Climate Change Mitigation: Policies and Options for Global Act ion beyond 2012. Paris: OECD.

Outlook, World Energy. 2008. Paris: International Energy Agency.

P. Poumanyvong, S. Kaneko. 2010. "Does urbanization lead to less energy use and lower CO2 emissions? A cross-country analysis." Ecological Economics 434-444.

P. Rickwood, G. Glazebrook, G. Searle. 2008. "Urban structure and energy - a review ." Urban Policy and Research 57-81.

Philippe Barlaa, Luis F., Miranda-Morenob, Martin Lee-Gosselina. 2011. "Urban travel CO2 emissions and land use: A case study for Quebec City." Environment 423-428.

Prospects, World Urbanization. 2009. Revision, Population Division, Department of Economic and Social Affairs. New York: the United Nations Secretariat.

R. Madlener, Y. Sunak. 2011. "Impacts of urbanization on urban structures and energy demand: what can we learn for urban energy planning and urbanization management? ." Sustainable Cities and Society 45-53.

R.V. O’Neill, J.R. Krummel, R.H. Gardner, G. Sugihara, B. Jackson, D.L. De Angelis, B.T. Milne, M.G. Turner, B. Zygmunt, S.W. Christensen, V.H. Dale, R.L. Graham. 1988. "Indices of landscape pattern ." Landscape Ecology 153-162.

Page $10 / 26$ 
Song, Y., \& Knaap, G.-J. 2004. "Measuring the effects of mixed land uses on housing values." Regional Science and Urban Economics 34, 663-680.

Steemers, K. 2003. "Energy and the city: building and transport ." Energy and Buildings 3-14.

Turner, M. G., Gardner, R. H., \& O’Neill, R. V. 2001. Landscape ecology in theory and practice: Pattern and process. New York: Springer.

Y. Chen, X. Li, Y. Zheng, Y. Guan, X. Liu. 2011. "Estimating the relationship between urban forms and energy consumption: a case study in the Pearl River Delta, 2005-2008." Landscape and Urban Planning 33-42.

Y. Chen, X. Li, Y. Zheng, Y. Guan, X. Liu. 2011. "Estimating the relationship between urban forms and energy consumption: a case study in the Pearl River Delta, 2005-2008." Landscape and Urban Planning 33-42.

Zagow, Maged. 2020. "Does mixed-use development in the metropolis lead to less carbon emissions?" Urban Climate.

\section{Declarations}

To be used for all articles, including articles with biological applications

\# Funding (not Funding)

\# Conflicts of interest/Competing interests (No)

\# Availability of data and material (upon request)

\# Code availability (Not applicable)

\# Authors' contributions (Not applicable)

\section{Footnotes}

[1] Using Census Feature Class Code (CFCC) values, Reid Ewing and Shima Hamidi filtered away all motorways, gravel tracks, and other roads without pedestrian access. The source data represented split highways, which from a pedestrian mobility standpoint perform similarly to undivided roadways of the same functional class, as pairs of (nearly) parallel centerline segments. Using GIS tools, they were combined into single segments after being detected by a CFCC value.

\section{Tables}

Table 1

climate zones definitions (Amanda D. Smith 2014)

\begin{tabular}{|l|l|}
\hline Climate zone & Description \\
\hline Climate zone 0 & Extremely Hot-Humid (0A), Dry (0B) \\
\hline Climate zone 1 & Very Hot - Humid (1A), Dry (1B) \\
\hline Climate zone 2 & Hot - Humid (2A), Dry (2B) \\
\hline Climate zone 3 & Warm - Humid (3A), Dry (3B) / Warm -Marin (3C) \\
\hline Climate zone 4 & Mixed - Humid (4A), Dry (4B) / Mixed -Marin (4C) \\
\hline Climate zone 5 & Cool - Humid (5A), Dry (5B) / Cool -Marin (5C) \\
\hline Climate zone 6 & Cold - Humid (6A), Dry (6B) \\
\hline Climate zone 7 & Very Cold (7) \\
\hline Climate zone 8 & Subarctic/Arctic (8) \\
\hline
\end{tabular}


Table 2

$\mathrm{CO}_{2}$ Emission Regression analysis Variables

\begin{tabular}{|c|c|c|}
\hline Variables & Definition & Source \\
\hline \multicolumn{3}{|l|}{ Dependent } \\
\hline $\mathrm{Co}_{2}$ emission & $\begin{array}{l}\text { Carbon emission in each } \\
\text { zip code }\end{array}$ & $\begin{array}{l}\text { This data is from CoolClimate Network - RAEL, UC Berkeley, the use of data is under } \\
\text { permission of Christopher M. Jones, Ph.D. Program Director }\end{array}$ \\
\hline $\begin{array}{l}\text { Number of } \\
\text { Businesses }\end{array}$ & $\begin{array}{l}\text { Total number of } \\
\text { Bussinesses in each zip } \\
\text { code }\end{array}$ & census-2016 \\
\hline walk score & $\begin{array}{l}\text { data is used to assess the } \\
\text { closeness of facilities in a } \\
\text { third mixed-use variable }\end{array}$ & (Hamidi 2010) \\
\hline \multicolumn{3}{|l|}{ Independent } \\
\hline \multicolumn{3}{|c|}{ Social and Economic } \\
\hline $\begin{array}{l}\text { Percentage of } \\
\text { Occupied } \\
\text { housing units }\end{array}$ & $\begin{array}{l}\text { Percentage of occupied } \\
\text { housing units to total } \\
\text { housing units in each zip } \\
\text { code }\end{array}$ & census-2010-zcta \\
\hline $\begin{array}{l}\text { Percent of } \\
\text { people using } \\
\text { public } \\
\text { transportation }\end{array}$ & $\begin{array}{l}\text { Percentage of people } \\
\text { using public } \\
\text { transportation }\end{array}$ & 'American Community Survey 2009-2013 \\
\hline $\begin{array}{l}\text { Environmental } \\
\text { and Wildlife } \\
\text { Organizations }\end{array}$ & $\begin{array}{l}\text { Number of } \\
\text { Environmental and } \\
\text { Wildlife Organizations in } \\
\text { each zip code }\end{array}$ & census-2010-zcta \\
\hline $\begin{array}{l}\text { Civic \& social } \\
\text { organizations }\end{array}$ & $\begin{array}{l}\text { Number of Civic \& social } \\
\text { organizations in each zip } \\
\text { code }\end{array}$ & census-2010-zcta \\
\hline $\begin{array}{l}\text { Vehicle miles } \\
\text { traveled }\end{array}$ & $\begin{array}{l}\text { Total miles driven by } \\
\text { Vehicle }\end{array}$ & 'American Community Survey 2009-2013 \\
\hline \multicolumn{3}{|l|}{ Type of facilities } \\
\hline $\begin{array}{l}\text { Education } \\
\text { facilities }\end{array}$ & $\begin{array}{l}\text { Number of education } \\
\text { facilities in each zip code }\end{array}$ & census-2016 \\
\hline $\begin{array}{l}\text { Accommodations } \\
\text { and food } \\
\text { services }\end{array}$ & $\begin{array}{l}\text { Number of } \\
\text { accommodations and } \\
\text { food services in each zip } \\
\text { code }\end{array}$ & census-2016 \\
\hline $\begin{array}{l}\text { Retail trade } \\
\text { facilities }\end{array}$ & $\begin{array}{l}\text { Number of retail facilities } \\
\text { in each zip code }\end{array}$ & census-2016 \\
\hline $\begin{array}{l}\text { Arts, } \\
\text { entertainment, } \\
\text { and recreation } \\
\text { facilities }\end{array}$ & $\begin{array}{l}\text { Number of arts, } \\
\text { entertainment, and } \\
\text { recreation facilities in } \\
\text { each zip code }\end{array}$ & census-2016 \\
\hline \multicolumn{3}{|l|}{ Urban Fabric } \\
\hline Street factor & $\begin{array}{l}\text { Average block size } \\
\text { excluding rural blocks of } \\
\text { more than one square } \\
\text { mile, percentage of small } \\
\text { urban blocks of less than } \\
\text { one hundredth of a } \\
\text { square mile }\end{array}$ & $\begin{array}{l}\text { Using Census Feature Class Code (CFCC) values, Reid Ewing and Shima Hamidi filtered } \\
\text { out all freeways, unpaved tracks, and other roadways that do not function as pedestrian } \\
\text { routes. Divided roadways, which from a pedestrian mobility perspective functions } \\
\text { similarly to undivided roadways of the same functional class, were represented in the } \\
\text { source data as pairs of (roughly) parallel centerline segments. These were identified by } \\
\text { a CFCC value and merged into single segments using GIS tools. }\end{array}$ \\
\hline
\end{tabular}

Table 3

Number of cases for each urban model

\begin{tabular}{|c|c|c|c|c|c|c|c|c|c|}
\hline Model & $\begin{array}{l}\text { Detroit } \\
\text { Metro }\end{array}$ & $\begin{array}{l}\text { Reno } \\
\text { Metro }\end{array}$ & $\begin{array}{l}\text { Columbus } \\
\text { Metro }\end{array}$ & $\begin{array}{l}\text { Chicago } \\
\text { Metro }\end{array}$ & $\begin{array}{l}\text { Boston } \\
\text { Metro }\end{array}$ & $\begin{array}{l}\text { Zone } 5 \\
\text { MICRO }\end{array}$ & $\begin{array}{l}\text { Zone } 5 \\
\text { METRO }\end{array}$ & $\begin{array}{l}\text { Zone } 5 \\
\text { CITEIS }\end{array}$ & $\begin{array}{l}\text { Zone } \\
5\end{array}$ \\
\hline $\begin{array}{l}\text { Number of } \\
\text { cases }\end{array}$ & 253 & 37 & 191 & 391 & 541 & 1483 & 4714 & 4066 & 8292 \\
\hline
\end{tabular}


Table 4

Pearson Correlation between $\mathrm{CO}_{2}$ emissions and urban Socioeconomics Variables.

\begin{tabular}{|c|c|c|c|c|c|c|c|c|c|c|c|c|}
\hline & walkscore & $\begin{array}{l}\text { Number of } \\
\text { Businesses }\end{array}$ & $\begin{array}{l}\operatorname{mix} \\
\text { factor }\end{array}$ & $\begin{array}{l}\text { Retail } \\
\text { Trade }\end{array}$ & Education & $\begin{array}{l}\text { Accommodation } \\
\text { and Food } \\
\text { Services }\end{array}$ & Health & $\begin{array}{l}\text { Arts, } \\
\text { Entertainment, } \\
\text { and } \\
\text { Recreation }\end{array}$ & Finance & \begin{tabular}{|l|} 
street \\
factor
\end{tabular} & \begin{tabular}{|l|} 
Percentage \\
of \\
Occupied \\
Housing \\
Units
\end{tabular} & \\
\hline All data & $-0.21 * *$ & $-0.11 * *$ & $0.02^{* *}$ & $-0.16 * *$ & $-0.04 * *$ & $-0.19 * *$ & $-0.11 * *$ & $-0.09 * *$ & $-0.07 * *$ & $0.07 * *$ & $0.23 * *$ & $-C$ \\
\hline Zoon 5 & $-0.22 * *$ & $-0.07 * *$ & $0.03^{* *}$ & $-0.15^{* *}$ & 0.00 & $-0.19 * *$ & $-0.12 * *$ & $-0.08 * *$ & $-0.06 * *$ & $0.10 * *$ & $0.12^{* *}$ & $-C$ \\
\hline Cities & $-0.39 * *$ & $-0.15^{* *}$ & $-0.16^{* *}$ & $-0.23^{* *}$ & $-0.04 *$ & $-0.30 * *$ & $-0.20 * *$ & $-0.15^{* *}$ & $-0.13^{* *}$ & $-0.04 *$ & $0.36^{* *}$ & $-C$ \\
\hline metro & $-0.35^{* *}$ & $-0.13^{* *}$ & $-0.13^{* *}$ & $-0.20 * *$ & -0.03 & $-0.27 * *$ & $-0.17 * *$ & $-0.13^{* *}$ & $-0.10^{* *}$ & $-0.03 *$ & $0.33^{* *}$ & $-\mathrm{E}$ \\
\hline Micro & $-0.11 * *$ & $-0.19 * *$ & 0.04 & $-0.21 * *$ & $-0.17 * *$ & $-0.22 * *$ & $-0.21 * *$ & $-0.18 * *$ & $-0.16^{* *}$ & 0.03 & $0.44^{* *}$ & $-C$ \\
\hline Boston & $-0.53^{*}$ & $-0.32 * *$ & $-0.13 * *$ & $-0.33 * *$ & $-0.23 * *$ & $-0.49 * *$ & $-0.32 * *$ & $-0.21 * *$ & $-0.21 * *$ & $-0.32 * *$ & $0.32^{* *}$ & $-C$ \\
\hline Chicago & $-0.40 * *$ & $-0.19 * *$ & $-0.26 * *$ & $-0.32 * *$ & -0.06 & $-0.35 * *$ & $-0.26 * *$ & $-0.30 * *$ & $-0.24^{* *}$ & $-0.21 * *$ & $0.12 *$ & $-C$ \\
\hline Columbus & $-0.47 * *$ & $-0.23 * *$ & $-0.21 * *$ & $-0.30 * *$ & $-0.17^{*}$ & $-0.30 * *$ & $-0.23^{* *}$ & -0.09 & -0.10 & -0.07 & $0.43^{* *}$ & $-\mathrm{C}$ \\
\hline Detroit & $-0.52 * *$ & $-0.19 * *$ & $-0.36 * *$ & $-0.35 * *$ & -0.10 & $-0.31 * *$ & $-0.13^{*}$ & -0.04 & -0.06 & $-0.28 * *$ & $0.63^{* *}$ & $-C$ \\
\hline
\end{tabular}

** Significant at the 0.01 level (2-tailed)

* Significant at the 0.05 level (2-tailed)

Table 5

Regression Analysis for Carbon Emissions, Number of Business and Walkscore for in All US zip codes, Climate zoon 5, Climate zoon 5 (

\begin{tabular}{|c|c|c|c|c|c|c|c|c|c|c|c|}
\hline \multirow[b]{3}{*}{ Variables } & \multirow{2}{*}{\multicolumn{3}{|c|}{ all US Zip codes }} & \multirow{2}{*}{\multicolumn{3}{|c|}{ Zoon 5}} & \multirow{2}{*}{\multicolumn{3}{|c|}{ Cities }} & \multirow{2}{*}{\multicolumn{2}{|c|}{ Metro }} \\
\hline & & & & & & & & & & & \\
\hline & $\begin{array}{l}\text { Carbon } \\
\text { Emissions }\end{array}$ & $\begin{array}{l}\text { Number of } \\
\text { Businesses }\end{array}$ & Walkscore & $\begin{array}{l}\text { Carbon } \\
\text { Emissions }\end{array}$ & $\begin{array}{l}\text { Number of } \\
\text { Businesses }\end{array}$ & Walkscore & \begin{tabular}{|l|} 
Carbon \\
Emissions
\end{tabular} & $\begin{array}{l}\text { Number of } \\
\text { Businesses }\end{array}$ & Walkscore & $\begin{array}{l}\text { Carbon } \\
\text { Emissions }\end{array}$ & $\begin{array}{l}\mathrm{N} \\
\mathrm{B} 1\end{array}$ \\
\hline (Constant) & 22.567 & -63.727 & 11.891 & 28.716 & -110.343 & 15.865 & 18.320 & -232.863 & 16.005 & 21.418 & $\overline{-2}$ \\
\hline Walkscore & 0.006 & & & -0.014 & & & -0.054 & & & -0.040 & \\
\hline $\begin{array}{l}\text { Number of } \\
\text { Businesses }\end{array}$ & 0.002 & & & & & & 0.005 & & & 0.007 & \\
\hline Mix Factor & 0.000 & 0.366 & 0.28 & 0.003 & 0.316 & 0.136 & -0.002 & 0.36 & 0.157 & 0.000 & 0. \\
\hline $\begin{array}{l}\text { Retail Trade } \\
\text { Stores }\end{array}$ & 0.001 & 1.674 & -0.005 & 0.004 & 1.562 & 0.025 & -0.006 & 1.628 & 0.027 & -0.006 & 1. \\
\hline $\begin{array}{l}\text { Education } \\
\text { Facilities }\end{array}$ & 0.079 & 5.847 & 0.082 & 0.082 & 3.166 & 0.054 & 0.070 & 2.852 & 0.057 & & \\
\hline $\begin{array}{l}\text { Accommodation } \\
\text { and Food } \\
\text { Services }\end{array}$ & -0.037 & 2.231 & 0.044 & -0.078 & 2.189 & 0.082 & -0.094 & 2.008 & 0.06 & -0.085 & 3. \\
\hline $\begin{array}{l}\text { Health } \\
\text { Facilities } \\
\end{array}$ & -0.001 & 1.036 & 0.018 & 0.006 & 1.272 & 0.016 & -0.006 & 1.328 & 0.006 & 0.000 & 2. \\
\hline $\begin{array}{l}\text { Arts, } \\
\text { Entertainment, } \\
\text { and Recreation } \\
\text { Facilities }\end{array}$ & -0.004 & 2.867 & -0.036 & 0.198 & 3.464 & -0.258 & 0.182 & 3.126 & -0.187 & 0.176 & 4. \\
\hline $\begin{array}{l}\text { Finance } \\
\text { Facilities }\end{array}$ & 0.012 & 3.188 & 0.03 & 0.032 & 3.227 & 0.04 & 0.018 & 3.233 & 0.046 & & \\
\hline Street Factor & 0.022 & -0.046 & -0.218 & 0.029 & 0.01 & -0.045 & 0.026 & 0.325 & -0.027 & 0.026 & 0. \\
\hline $\begin{array}{l}\text { Mean Vehicle } \\
\text { miles traveled }\end{array}$ & 0.001 & & -0.001 & 0.001 & -0.001 & & 0.001 & -0.002 & & 0.001 & -0 \\
\hline $\begin{array}{l}\text { Percentage of } \\
\text { occupied } \\
\text { Housing Units }\end{array}$ & 1.870 & 24.679 & 1.292 & 1.883 & 12.405 & 2.005 & 20.367 & 83.218 & 8.586 & 14.705 & $4 i$ \\
\hline $\begin{array}{l}\text { Percentage of } \\
\text { people using } \\
\text { public } \\
\text { transportation }\end{array}$ & -0.027 & 1.161 & 0.496 & -0.117 & 1.894 & 1.461 & -0.046 & 1.477 & 1.303 & -0.083 & 0. \\
\hline $\begin{array}{l}\text { Environmental } \\
\text { and Wildlife } \\
\text { Organizations }\end{array}$ & -0.445 & 21.157 & 0.173 & -0.827 & 22.539 & -0.154 & -0.836 & 25.602 & 0.089 & -0.846 & 37 \\
\hline $\begin{array}{l}\text { Total } \\
\text { (tCO2e/yr) }\end{array}$ & & 1.131 & 0.078 & & 2.691 & -0.108 & & 3.25 & -0.379 & & 4. \\
\hline $\begin{array}{l}\text { Adjusted R } \\
\text { Square }\end{array}$ & 0.69 & 0.92 & 0.65 & 0.64 & 0.88 & 0.55 & 0.63 & 0.85 & 0.55 & 0.63 & 0. \\
\hline $\mathrm{N}$ & \multicolumn{3}{|l|}{28122} & \multicolumn{3}{|l|}{8292} & \multicolumn{3}{|l|}{4066} & \multicolumn{2}{|l|}{4714} \\
\hline
\end{tabular}


Table 6

Regression Analysis for Carbon Emissions, Number of Business and Walkscore for in Boston, Chicago, Columbus, and De

\begin{tabular}{|c|c|c|c|c|c|c|c|c|c|c|c|}
\hline \multirow[b]{2}{*}{ Variables } & \multicolumn{3}{|l|}{ Boston } & \multicolumn{3}{|l|}{ Chicago } & \multicolumn{3}{|l|}{ Columbus } & \multicolumn{2}{|l|}{ Detroit } \\
\hline & $\begin{array}{l}\text { Carbon } \\
\text { Emissions }\end{array}$ & $\begin{array}{l}\text { Number of } \\
\text { Businesses }\end{array}$ & Walkscore & $\begin{array}{l}\text { Carbon } \\
\text { Emissions }\end{array}$ & $\begin{array}{l}\text { Number of } \\
\text { Businesses }\end{array}$ & Walkscore & $\begin{array}{l}\text { Carbon } \\
\text { Emissions }\end{array}$ & \begin{tabular}{|l|} 
Number of \\
Businesses
\end{tabular} & Walkscore & $\begin{array}{l}\text { Carbon } \\
\text { Emissions }\end{array}$ & $\begin{array}{l}\mathrm{N} \\
\mathrm{B} 1\end{array}$ \\
\hline (Constant) & 17.759 & -93.612 & 0.151 & 12.555 & \begin{tabular}{|l|}
-291.778 \\
\end{tabular} & 17.727 & 25.207 & \begin{tabular}{|l|}
-17.54 \\
\end{tabular} & 5.252 & 14.407 & $\overline{-1}$ \\
\hline Walkscore & 0.042 & & & 0.092 & & & -0.003 & & & 0.009 & \\
\hline $\begin{array}{l}\text { Number of } \\
\text { Businesses }\end{array}$ & -0.001 & & & 0.002 & & & -0.003 & & & -0.002 & \\
\hline Mix Factor & -0.013 & 0.002 & 0.043 & -0.048 & 3.919 & 0.557 & 0.013 & -0.574 & 0.65 & 0.004 & $\overline{0 .}$ \\
\hline $\begin{array}{l}\text { Retail Trade } \\
\text { Stores }\end{array}$ & -0.007 & 1.783 & 0.014 & -0.006 & 0.052 & -0.004 & 0.003 & 1.213 & 0.005 & 0.009 & 1. \\
\hline $\begin{array}{l}\text { Education } \\
\text { Facilities }\end{array}$ & 0.164 & 7.595 & 0.57 & 0.008 & 0.543 & & 0.311 & 1.299 & 0.016 & 0.246 & 10 \\
\hline $\begin{array}{l}\text { Accommodation } \\
\text { and Food } \\
\text { Services }\end{array}$ & -0.033 & 1.68 & 0.021 & -0.019 & 4.927 & 0.027 & -0.065 & 3.116 & -0.048 & -0.061 & 1. \\
\hline $\begin{array}{l}\text { Health } \\
\text { Facilities }\end{array}$ & 0.015 & 1.851 & -0.011 & 0.008 & 0.691 & -0.03 & -0.002 & 0.946 & -0.013 & 0.006 & 0. \\
\hline $\begin{array}{l}\text { Arts, } \\
\text { Entertainment, } \\
\text { and Recreation } \\
\text { Facilities }\end{array}$ & 0.100 & 2.447 & -0.199 & -0.070 & -1.861 & -0.043 & 0.213 & 9.785 & 0.219 & 0.118 & 5. \\
\hline $\begin{array}{l}\text { Finance } \\
\text { Facilities }\end{array}$ & 0.012 & 2.753 & 0.031 & 0.014 & 0.558 & 0.024 & 0.042 & 3.123 & -0.004 & 0.038 & 4. \\
\hline Street Factor & 0.020 & 0.377 & 0.067 & 0.057 & -2.53 & -0.447 & 0.007 & 0.801 & -0.698 & 0.046 & $\overline{-0}$ \\
\hline $\begin{array}{l}\text { Mean Vehicle } \\
\text { miles traveled }\end{array}$ & 0.001 & 0.002 & -0.004 & 0.002 & -0.031 & -0.001 & 0.001 & 0.001 & -0.001 & 0.001 & 0. \\
\hline $\begin{array}{l}\text { Percentage of } \\
\text { occupied } \\
\text { Housing Units }\end{array}$ & -6.277 & 59.221 & 40.991 & 0.477 & 84.093 & -8.271 & 2.300 & 30.314 & 23.733 & 1.649 & 11 \\
\hline $\begin{array}{l}\text { Percentage of } \\
\text { people using } \\
\text { public } \\
\text { transportation }\end{array}$ & 0.025 & -0.985 & 0.498 & 0.193 & -12.98 & 0.08 & -0.363 & 7.585 & -0.103 & 0.056 & -3 \\
\hline $\begin{array}{l}\text { Environmental } \\
\text { and Wildlife } \\
\text { Organizations }\end{array}$ & -0.143 & -6.198 & -1.075 & -0.227 & 98.68 & -1.076 & -0.749 & -22.337 & 1.769 & -0.164 & -3 \\
\hline $\begin{array}{l}\text { Total } \\
\text { (tCO2e/yr) }\end{array}$ & & -0.273 & 1.529 & & 19.529 & 0.486 & & -0.959 & -0.024 & & -1 \\
\hline $\begin{array}{l}\text { Adjusted R } \\
\text { Square }\end{array}$ & 0.93 & 0.96 & 0.61 & 0.85 & 0.56 & 0.88 & 0.87 & 0.99 & 0.85 & 0.905 & 0. \\
\hline $\mathrm{N}$ & \multicolumn{3}{|l|}{541} & \multicolumn{3}{|l|}{391} & \multicolumn{3}{|l|}{191} & \multicolumn{2}{|l|}{253} \\
\hline
\end{tabular}

\section{Figures}




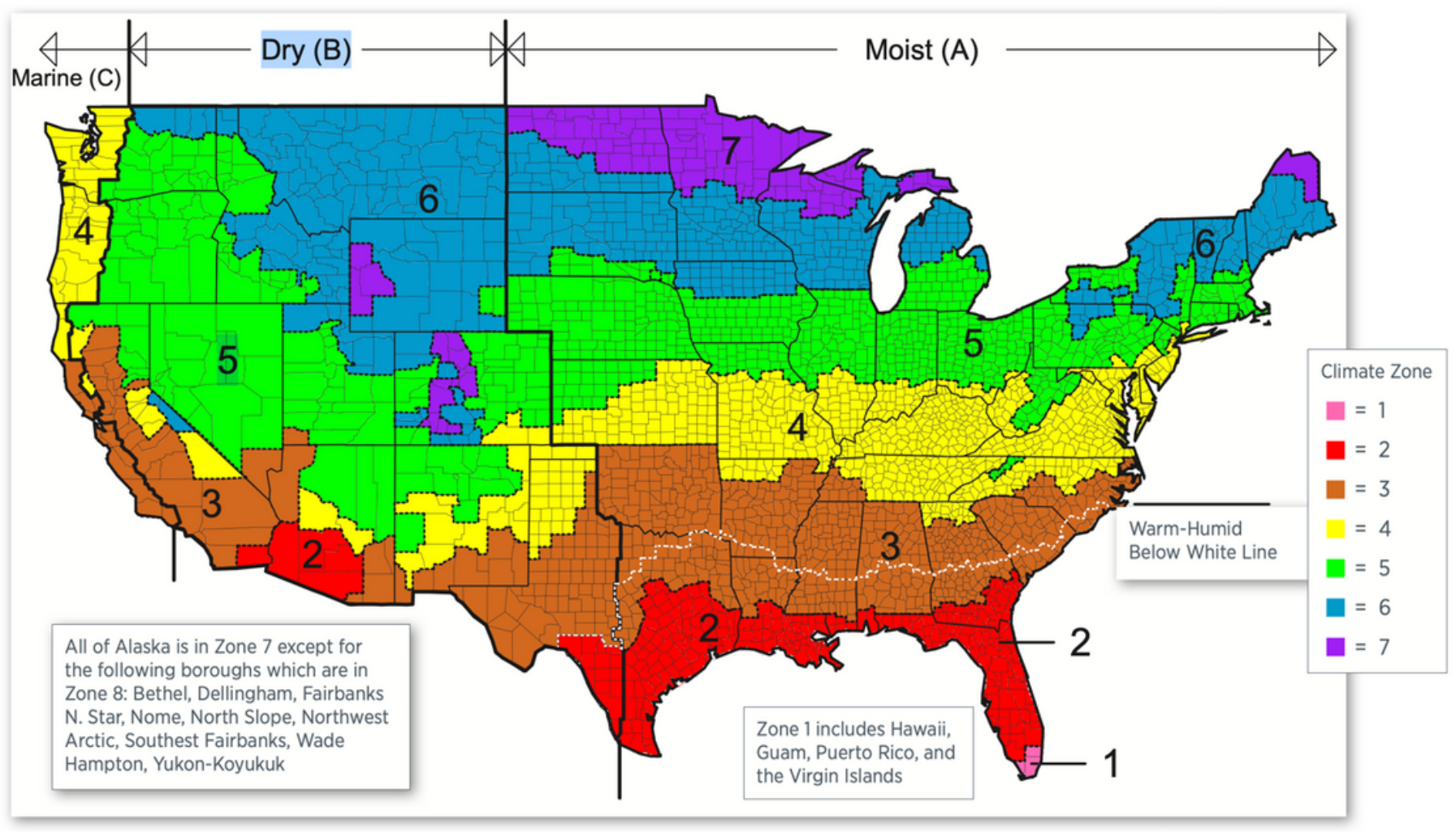

Figure 2. International Energy Conservation Code (IECC) climate regions

\section{Figure 1}

US climate regions (Council 2012) 


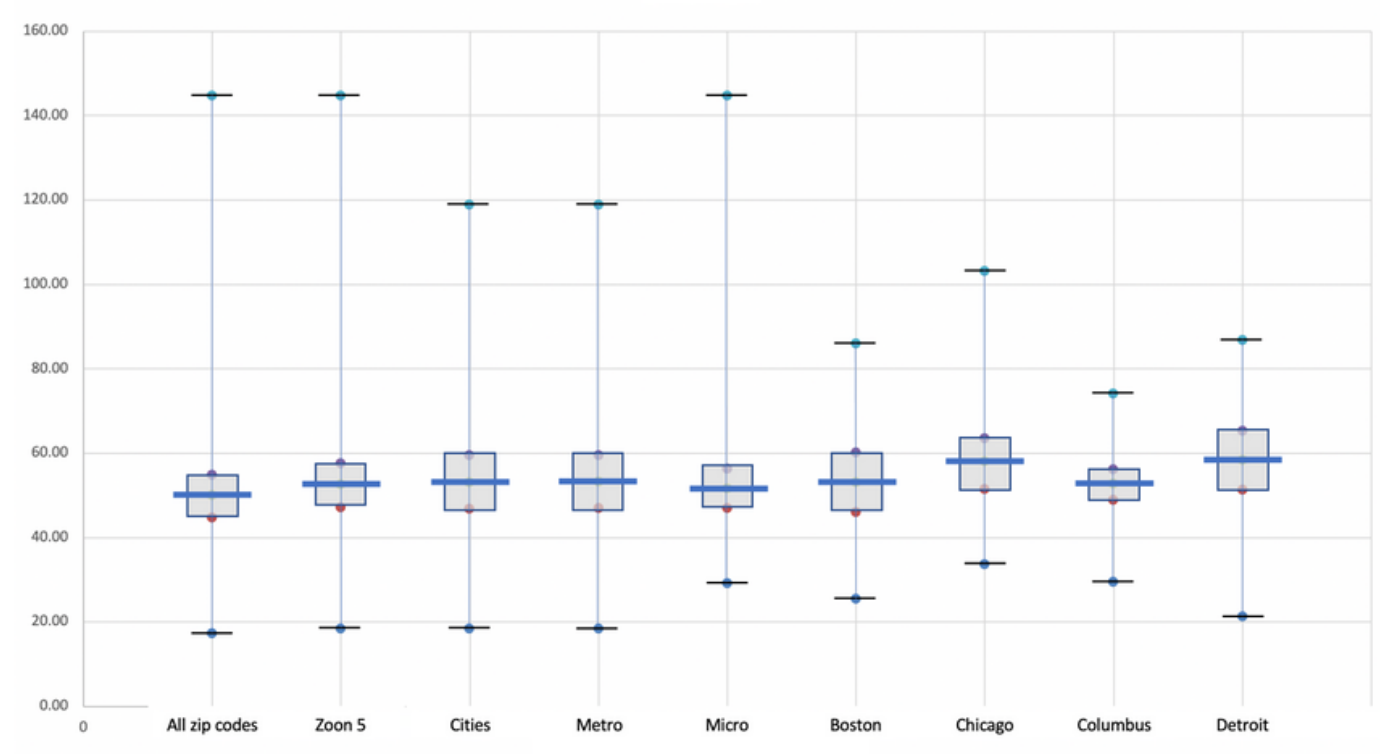

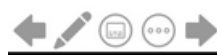

Figure 2

Descriptive Statistics of $\mathrm{CO}_{2}$ emissions for each model 


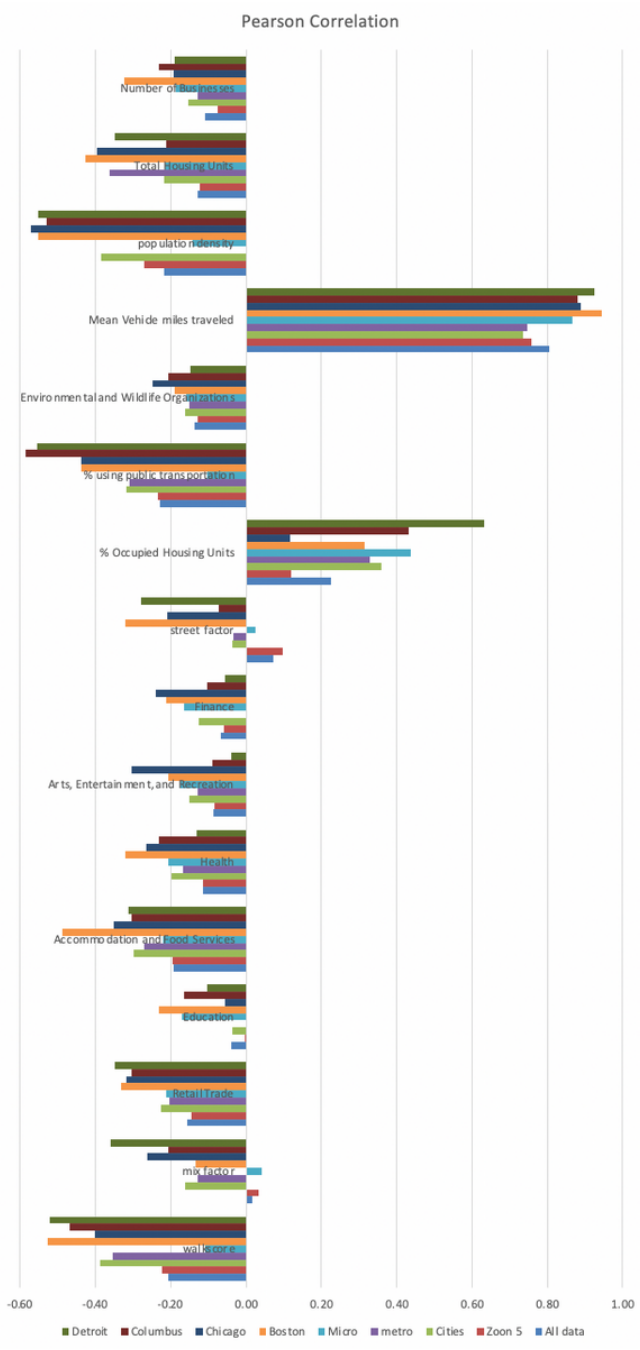

Figure 3

Pearson Correlation between $\mathrm{CO} 2$ emissions and urban Socioeconomics Variables. 


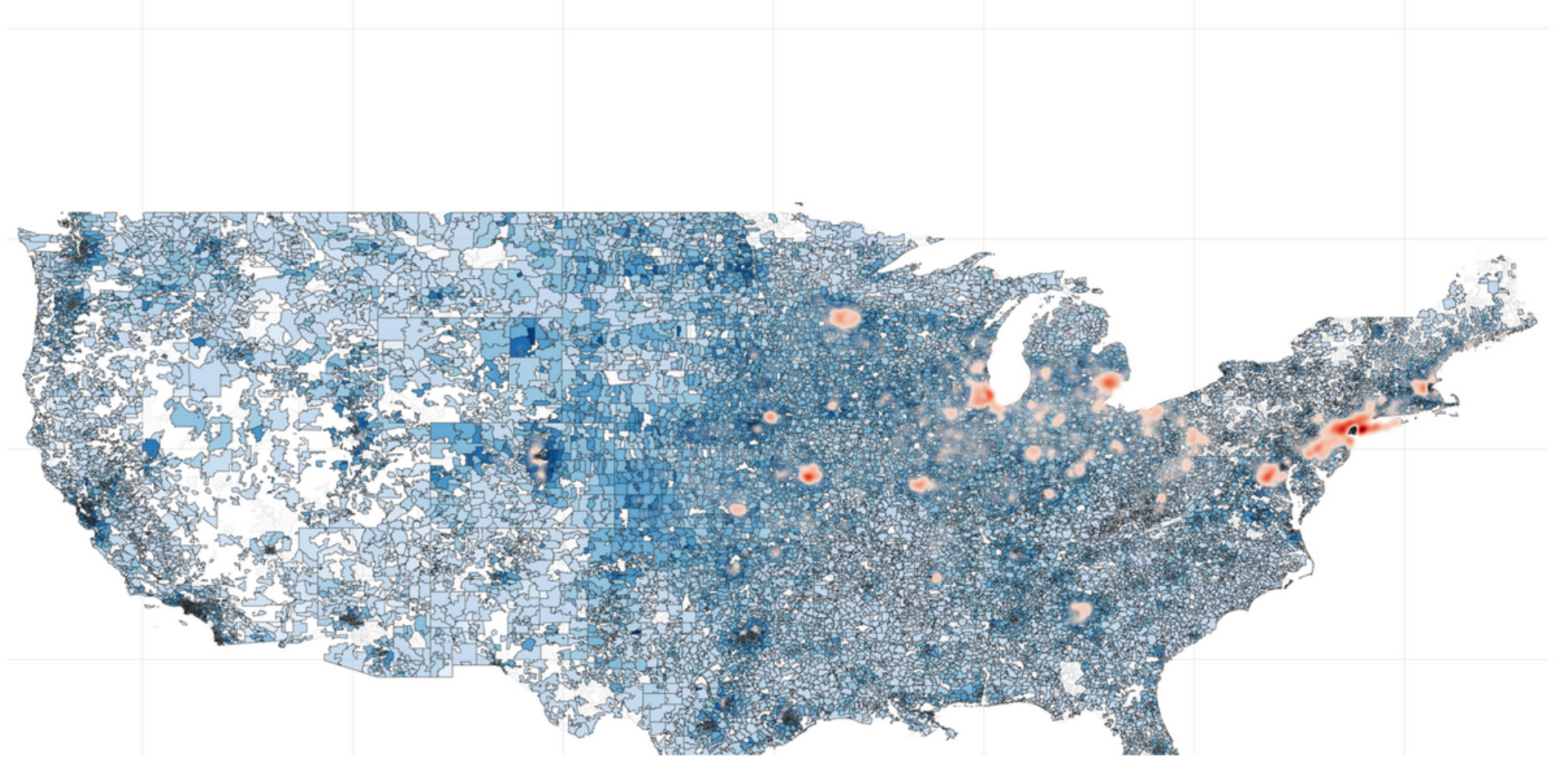

Figure 4

Heat map based on residuals extracted from a regression featuring $\mathrm{CO}_{2}$ emissions for All US zip codes. 


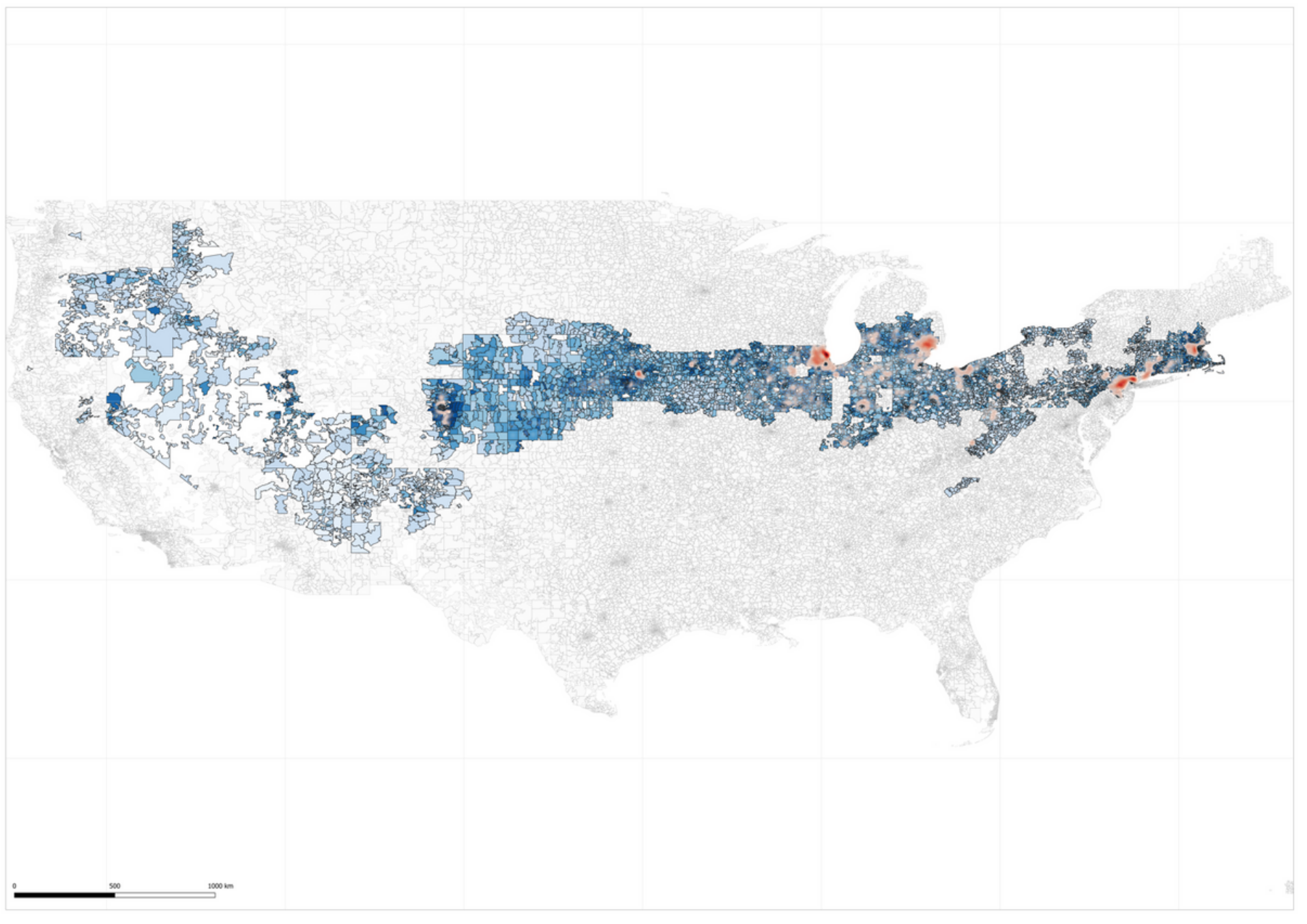

Figure 5

Heat map based on residuals extracted from a regression featuring $\mathrm{CO}_{2}$ emissions for Cool climate zone 5 zip codes 


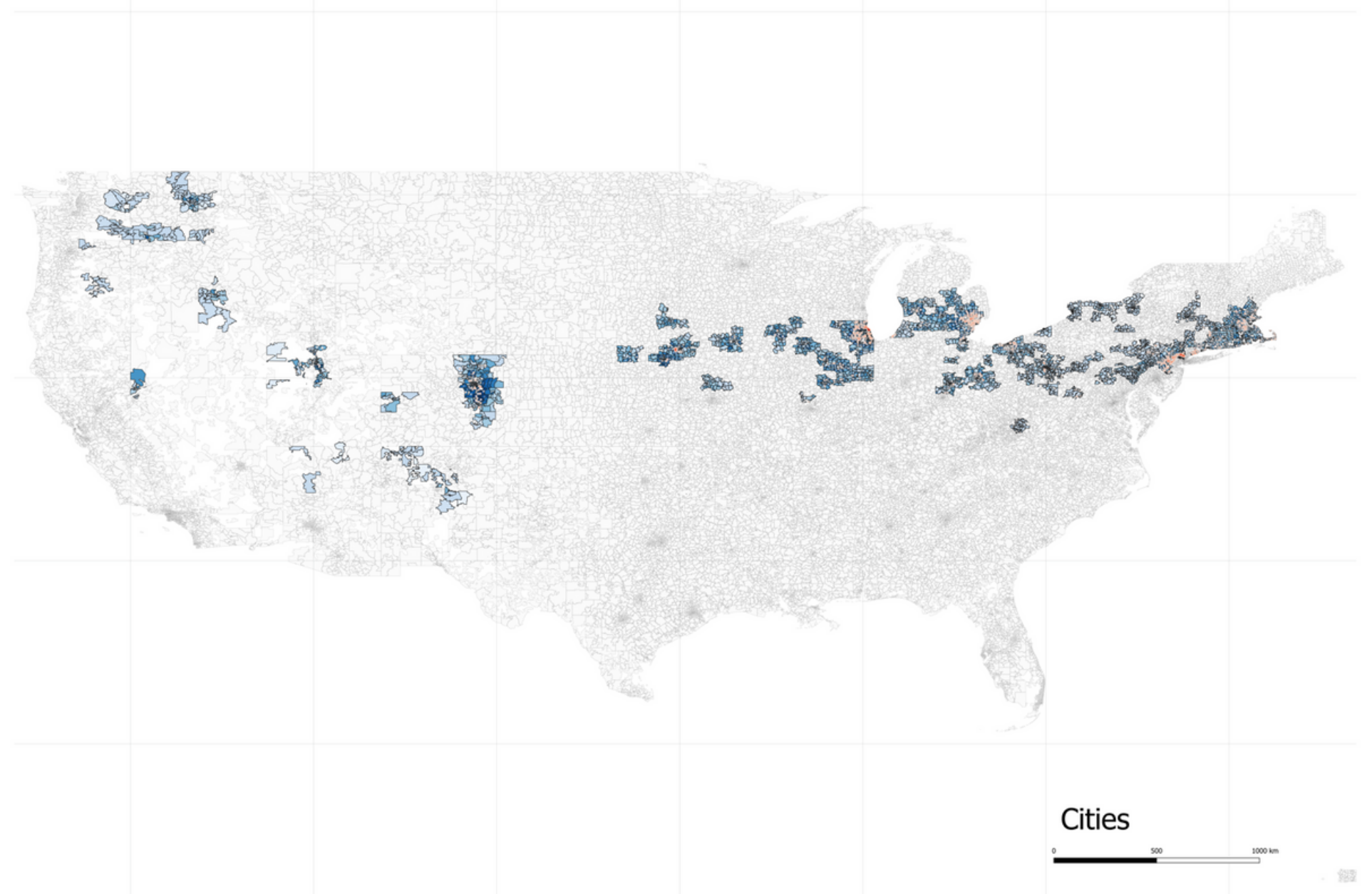

Figure 6

Heat map based on residuals extracted from a regression featuring $\mathrm{CO}_{2}$ emissions for Cool climate zone 5 cities zip codes 


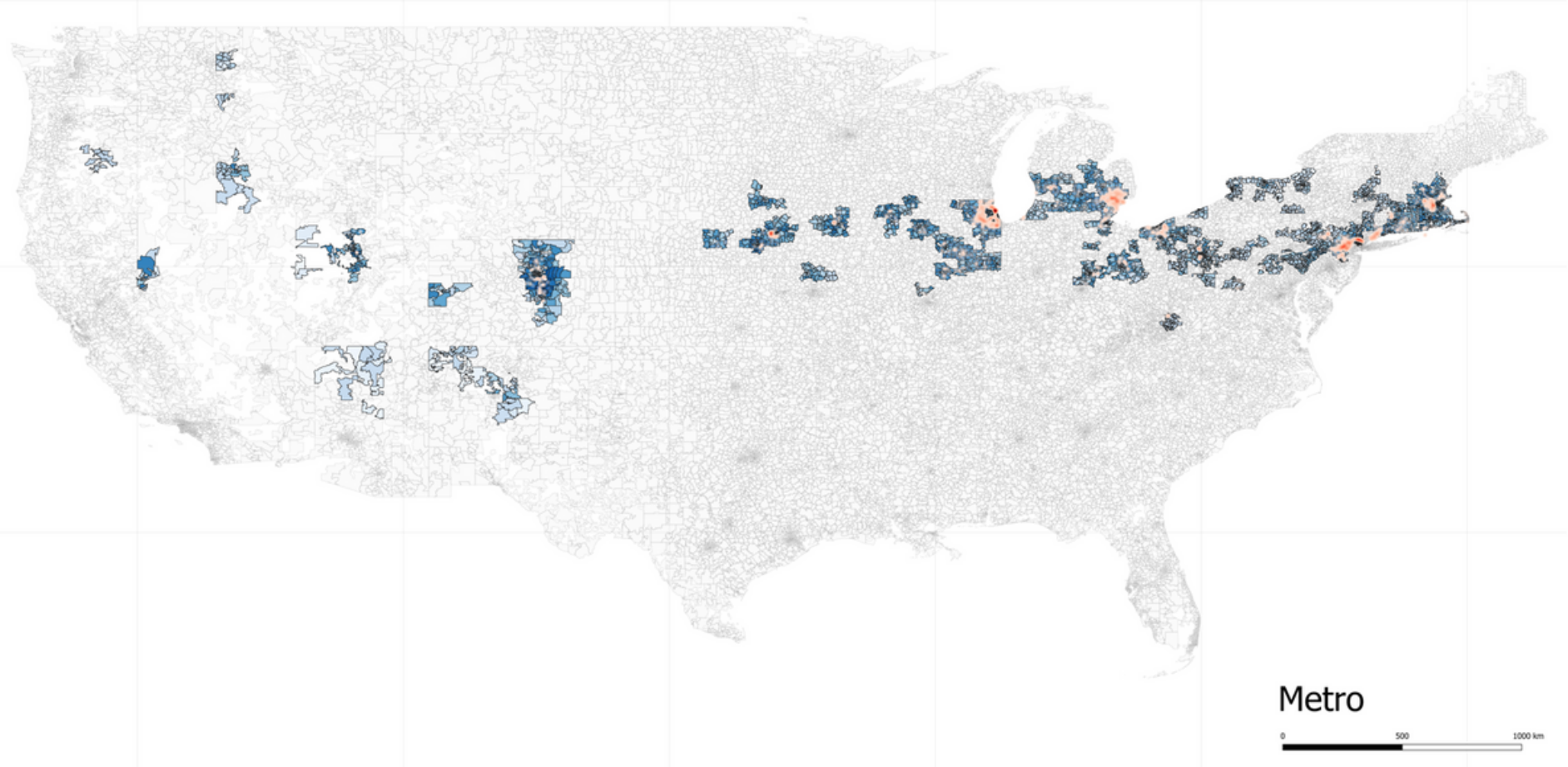

Figure 7

Heat map based on residuals extracted from a regression featuring $\mathrm{CO}_{2}$ emissions for Cool climate zone 5 Metro zip codes 


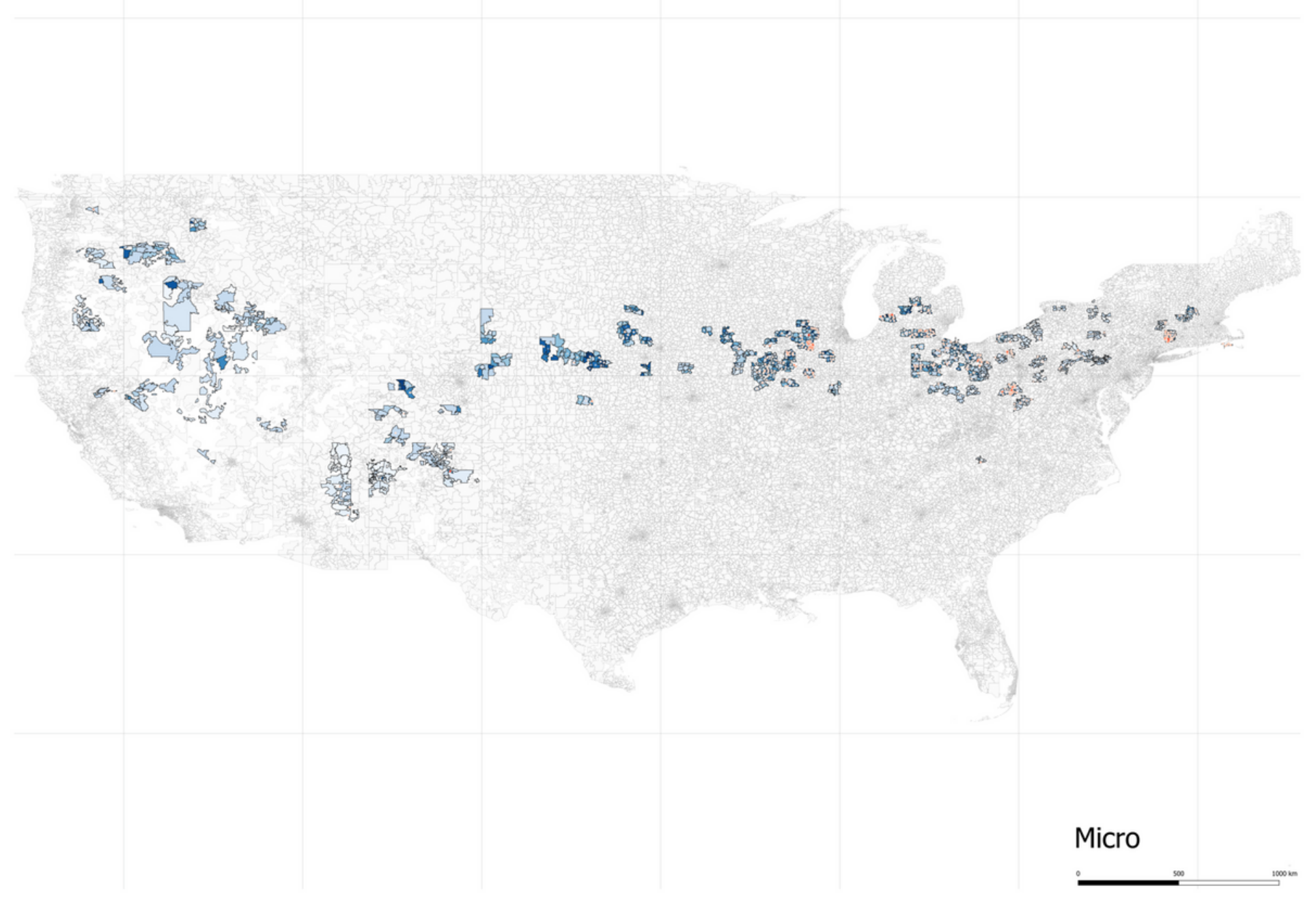

Figure 8

Heat map based on residuals extracted from a regression featuring $\mathrm{CO}_{2}$ emissions for Cool climate zone 5 Micro zip codes 


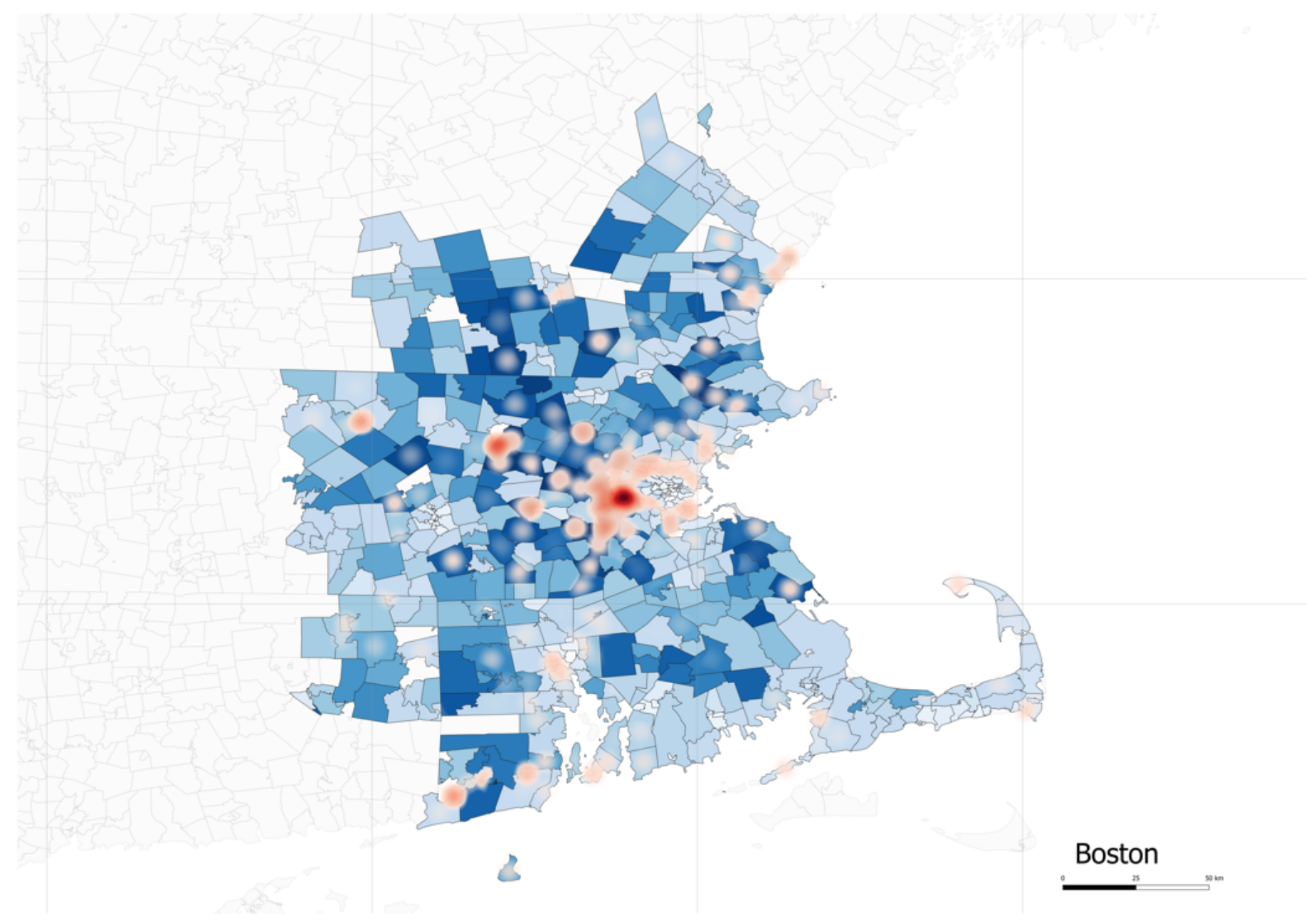

Figure 9

Heat map based on residuals extracted from a regression featuring $\mathrm{CO}_{2}$ emissions for Boston Metro zip codes 


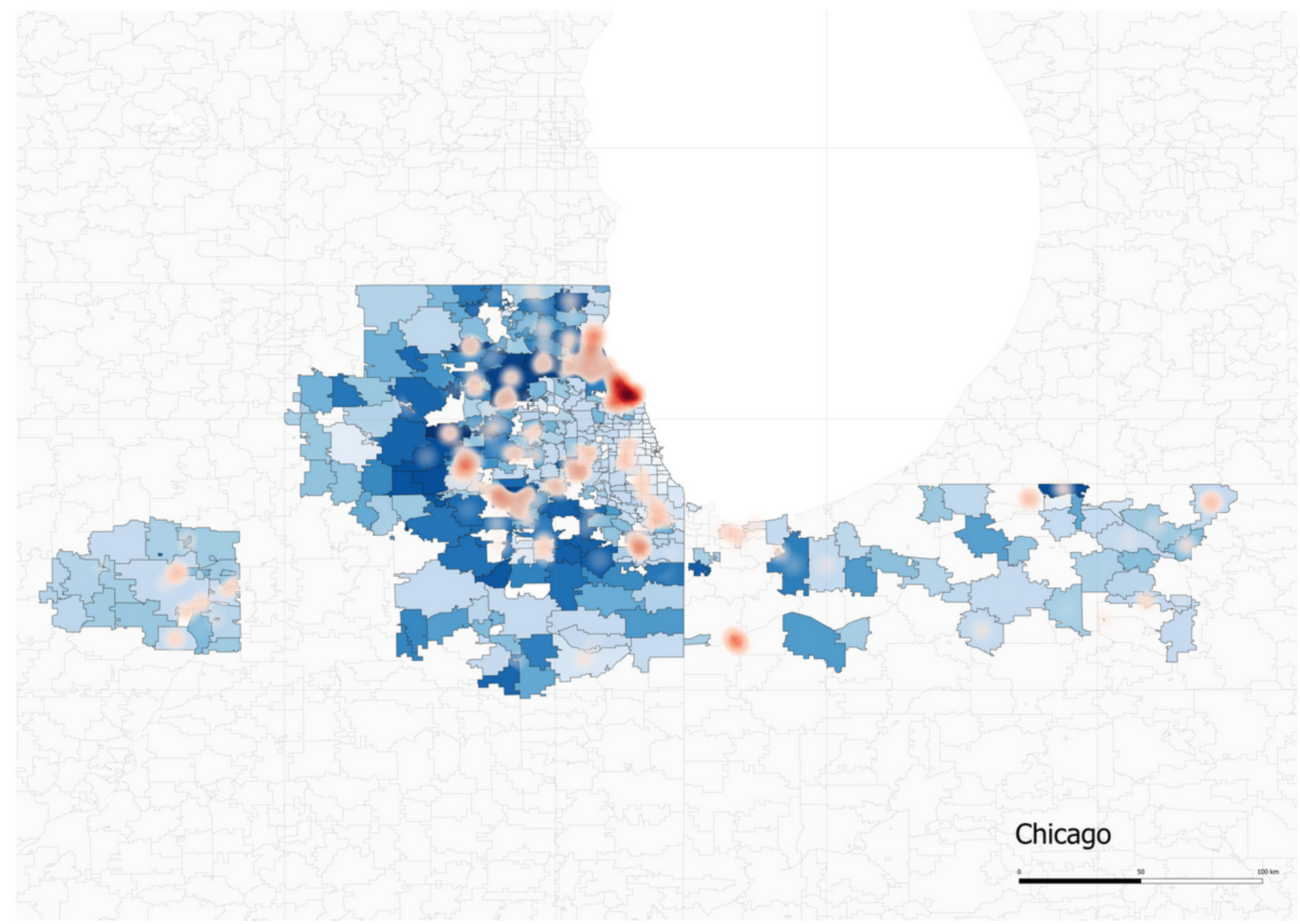

\section{Figure 10}

Heat map based on residuals extracted from a regression featuring $\mathrm{CO}_{2}$ emissions for Chicago Metro zip codes 


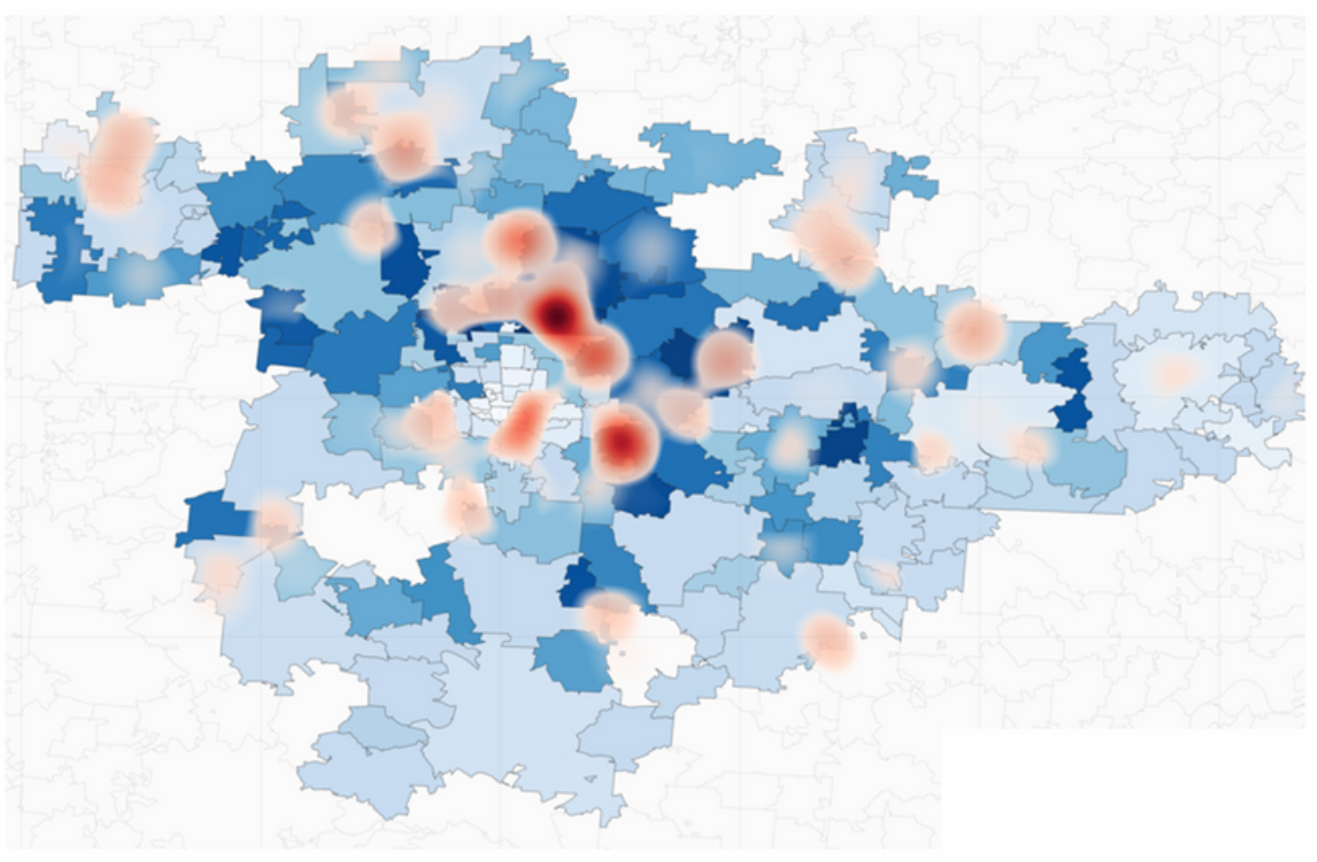

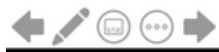

Figure 11

Heat map based on residuals extracted from a regression featuring $\mathrm{CO}_{2}$ emissions for Columbus Metro zip codes 


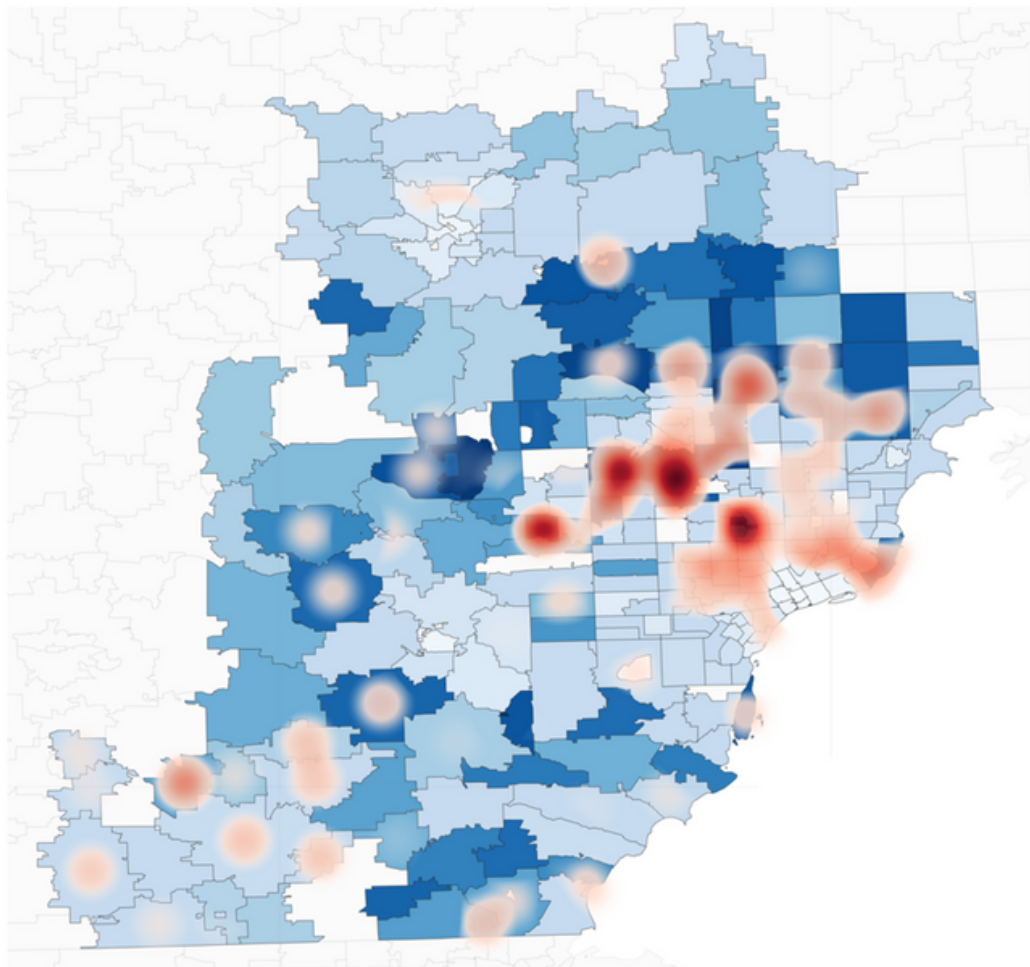

$4 ; \circ \Rightarrow$

Figure 12

Heat map based on residuals extracted from a regression featuring $\mathrm{CO}_{2}$ emissions for Detroit Metro zip codes 